Illinois State University

ISU ReD: Research and eData

Theses and Dissertations

5-3-2017

\title{
Evaluating Fault-Line Escarpment exposure in the Guadalupe Mountains of west Texas and New Mexico
}

Audrey Anne Happel

Illinois State University, aahappe@ilstu.edu

Follow this and additional works at: https://ir.library.illinoisstate.edu/etd

Part of the Geology Commons, and the Geomorphology Commons

\section{Recommended Citation}

Happel, Audrey Anne, "Evaluating Fault-Line Escarpment exposure in the Guadalupe Mountains of west Texas and New Mexico" (2017). Theses and Dissertations. 756.

https://ir.library.illinoisstate.edu/etd/756

This Thesis is brought to you for free and open access by ISU ReD: Research and eData. It has been accepted for inclusion in Theses and Dissertations by an authorized administrator of ISU ReD: Research and eData. For more information, please contact ISUReD@ilstu.edu. 


\title{
EVALUATING FAULT-LINE ESCARPMENT EXPOSURE IN THE
}

\section{GUADALUPE MOUNTAINS OF WEST TEXAS}

\author{
AND NEW MEXICO
}

\author{
Audrey A. Happel
}

\section{Pages}

The Permian stratigraphy of the Guadalupe Mountains is well-known due to the impeccable exposure of Permian strata along distinct escarpments that define the boundaries of the range. Even though the Permian strata have been closely examined to understand the associated petroleum reservoirs in the adjacent Delaware basin, little work has been done on the escarpments that expose the well-known rocks at the surface by way of tectonic and erosional processes. The development of escarpments are directly affected by multiple processes that create the landscape, and can be used as a tool to temporally and spatially constrain tectonic and erosional activity (Phillips et al., 2003). Distinct fault escarpments define the western margin of the range and provide an interesting location to study interactions between climatic, tectonic and erosional processes using bedrock exposure near the Rio Grande Rift. In-situ produced cosmogenic nuclides, ${ }^{10} \mathrm{Be}$ and ${ }^{36} \mathrm{Cl}$, are used as tools to effectively measure the exposure of bedrock surfaces along western escarpments in the Guadalupe Mountains. In total, ten bedrock samples were collected from the top and bottom of five different mapped fault segments to measure exposure ages and erosion rates along the western boundary of the mountain range to learn about the geomorphic history of the region. The cosmogenic nuclide concentrations measured in these rock samples were used to calculate exposure ages, which resulted in 
Pleistocene exposure ages. Results also indicate the landscape achieved steady-state conditions, suggesting that the mechanisms driving erosion in this tectonic and climatic regime have remained similar over the timescale represented. Spatial comparison of the age results show a general increase in exposure age from south to north. Another trend observed in the data is a tendency for younger exposure ages at the top of the escarpment than at corresponding bottom locations. Furthermore, five out of ten samples exhibit exposure ages that correspond to the last glacial maximum, including four locations in the southern portion of the range, three of which are top samples. Local climate variation due to elevation change along the escarpment is a key component in erosional processes taking place because temperature decreases as elevation increases. The increase in elevation increases precipitation, wind velocity, and erosional processes, resulting in younger exposure ages at the top and backward migration of the escarpment. The greater number of faults in the southern portion of the range may contribute to younger exposure ages, however, the number and location of samples limit the information necessary to fully interpret and understand all the geomorphic conditions in the region. The Guadalupe Mountains prove to have an interesting history incorporating some components of climatic, tectonic, and erosional process interactions that shaped the landscape. Continued work on surface processes throughout the region is necessary to better constrain the geomorphic history of the Guadalupe Mountains.

KEYWORDS: Cosmogenic-nuclide geochronology; ${ }^{10} \mathrm{Be} ;{ }^{36} \mathrm{Cl}$; Exposure dating; Erosion rate measurements 


\title{
EVALUATING FAULT-LINE ESCARPMENT EXPOSURE IN THE GUADALUPE MOUNTAINS OF WEST TEXAS \\ AND NEW MEXICO
}

\author{
AUDREY A. HAPPEL
}

A Thesis Submitted in Partial Fulfillment of the Requirements for the Degree of

MASTER OF SCIENCE

Department of Geography-Geology

\section{ILLINOIS STATE UNIVERSITY}


(C) 2017 Audrey A. Happel 


\section{EVALUATING FAULT-LINE ESCARPMENT EXPOSURE IN THE}

GUADALUPE MOUNTAINS OF WEST TEXAS

AND NEW MEXICO

AUDREY A. HAPPEL

COMMITTEE MEMBERS:

Lisa Tranel, Chair

David Malone

Eric Peterson 


\section{ACKNOWLEDGMENTS}

I would first like to thank my thesis advisor Dr. Lisa Tranel whose patience, guidance, and knowledge of the project led to its completion. I am forever grateful for your help. I would also like to thank my committee members Dr. David Malone and Dr. Eric Peterson for their time and willingness to help me through this process. In addition, I want to include and thank, Dr. Skip Nelson for his time, willingness, and knowledge that helped me through this process.

I would also like to thank Jeremy Neundorff, Kacey Garber, Kirsten Schaefer, and Chad Cremer for helping me retrieve my samples during field work in March 2016. In addition to field work, I want to thank Jeremy Neundorff, Kacey Garber, Kirsten Schaffer and Jeremy Babin for helping with the physical treatment of my samples at ISU. In addition, I would like to thank Dr. Wondwosen Seyoum for teaching me how to use MATLAB and help in calculating my exposure ages. I would also like to thank Dr. Tenley Banik for insight into the interpretation of my bulk rock data. I would like to thank Sam Schoenmann for the Arc Toolbox with profile tool that created my profiles.

I would also like to thank Purdue University's PRIME lab's Tom Clifton and Greg Chmiel for letting me take part in the chemical treatment of my samples. I would like to thank Ms. Karen Dunton and my fellow graduate students for their unconditional support throughout my time at ISU.

This thesis is dedicated to my parents, Robert and Anne Happel for helping me to achieve my goals and always believing in me every step of the way. Without their unconditional love and support, I would not have been able to complete my thesis. I am forever grateful. 


\section{CONTENTS}

\section{Page}

ACKNOWLEDGMENTS

CONTENTS

ii

TABLES

iv

FIGURES

V

EQUATIONS - vi

CHAPTER I: INTRODUCTION 1

$\begin{array}{ll}\text { Background } & 6\end{array}$

$\begin{array}{ll}\text { Guadalupe Mountains } & 6\end{array}$

Rio Grande Rift $\quad 10$

Geomorphology of normal faults scarps and slopes 11

$\begin{array}{ll}\text { Cosmogenic Nuclides } & 13\end{array}$

$\begin{array}{ll}\text { CHAPTER II: METHODOLOGY } & 15\end{array}$

$\begin{array}{ll}\text { Field work } & 15\end{array}$

$\begin{array}{ll}\text { Cosmogenic Analysis } & 19\end{array}$

$\begin{array}{ll}\text { Physical Treatment } & 19\end{array}$

$\begin{array}{ll}\text { Chemical Treatment } & 20\end{array}$

${ }^{10} \mathrm{Be} \quad 20$

${ }^{36} \mathrm{Cl} \quad 21$

$\begin{array}{ll}\text { Calculations } & 22\end{array}$

$\begin{array}{ll}\text { Shielding Factors } & 22\end{array}$ 
Exposure Age

${ }^{10} \mathrm{Be}$

${ }^{36} \mathrm{Cl}$

Erosion Rate

CHAPTER III: RESULTS

CHAPTER IV: DISCUSSION

CHAPTER V: CONCLUSION

REFERENCES 


\section{TABLES}

Table

Page

1. List of cosmogenic nuclides with respective half-life target minerals

2. Field Data collected in March 2013, 2016, and November 2014

3. Rock and weathering descriptions for samples collected for cosmogenic analysis

4. Results for cosmogenic analysis of sandstone samples analyzed for ${ }^{10} \mathrm{Be}$

5. Results for ${ }^{36} \mathrm{Cl}$ cosmogenic Analysis

6. Results for steady-state calculations 


\section{FIGURES}

Figure

1. Photo of the Rim (western escarpment) near Dog Canyon 4

2. Study Site Location Map 5

3. Location of the Delaware Basin and exposed Capitan Reef complex $\quad 7$

4. Stratigraphic cross section of the Guadalupe Mountains 8

5. Permian rock formations in stratigraphic provinces 9

6. Image of samples collected for cosmogenic analysis 17

7. Study site map labeled with results of cosmogenic analysis 30

8. Wood's Canyon exposure ages vs elevation 32

9. Remaining four locations exposure age vs elevation 33

10. Exposure ages of top samples $\quad 34$

11. Exposure Ages of Bottom Samples 35

12. Profiles of escarpments with sample location and exposure age 38

13. Profiles of remaining escarpments 39

14. Exposure ages are plotted against corresponding elevations 44

15. Cross section of the Rim 45

16. Geologic Map of the Study Site 47

17. Stratigraphic column of reef and backreef deposits encountered in the study site 48

18. Stratigraphic column of basin deposits encountered in the study site 49

19. Profiles of sampled escarpments 50

20. Profile of Wood's Canyon escarpment $\quad 51$ 


\section{EQUATIONS}

Equation $\quad$ Page

1. Exposure Age Calculation 26

2. Exposure Age Calculation 26

3. Erosion Rate Calculation 26

$\begin{array}{ll}\text { 4. Steady-State Calculation } & 26,31\end{array}$ 


\section{CHAPTER I: INTRODUCTION}

The shape of the Earth's surface is constantly changing due to interactions between tectonic, climatic, and erosional processes. The Guadalupe Mountains, sitting in the arid climate near the boundary of modern-day stable tectonic regime, are not immune from the complex interactions and influences of these geologic processes. The Guadalupe Mountains of west Texas and New Mexico are positioned on the border of two tectonically different terrains in North America, between the Rio Grande Rift and the Great Plains. This boundary is a first order geological and geophysical boundary between the tectonically active western United States and the continental craton (Reiter and Chamberlin, 2011). The North American continent is experiencing extension in the southwestern portion of the United States. The zone of continental rifting includes the Basin and Range Province located in Nevada, and parts of Idaho, Utah, Arizona, California, Wyoming, Oregon, and Mexico. The narrow Rio Grande Rift extends from western Texas through New Mexico into Colorado.

Most studies completed in the Guadalupe Mountains focus on the Permian stratigraphy that extends into the adjacent Delaware Basin due to the associated petroleum reservoirs. However, little work has been completed to constrain the processes that expose the Permian Strata. Recent studies on cave formation and exhumation of the range begin to provide insight into the recent geologic and geomorphic history. One study on cave formation in the Guadalupe Mountains used ${ }^{40} \mathrm{Ar} /{ }^{39} \mathrm{Ar}$ dating of the mineral alunite, which forms during hypogenic cave genesis (Polyak et al., 1999). Alunite ages increase with cave elevation and fall into two main groups; 12-11 Ma minerals formed between an elevation of 2010-2040 meters and 6-4 Ma minerals formed between elevations of 1230-1090 meters (Polyak et al., 1999). Cave elevations 
indicate that between $12 \mathrm{Ma}$ and the present, the water table dropped approximately 900 meters (Polyak et al., 1999). The ages and elevations correspond to the maximum vertical displacement of the Guadalupe block and indicate that cave formation is linked to the Rio Grande Rift. In addition to studies on cave formation, the exhumation of the Guadalupe Mountains and Sacramento Mountains were studied using (U-Th)/He low temperature thermochronology (AHe) to date the bedrock cooling history with the mineral apatite (Hoffman, 2014). Results from AHe analysis range between 25-28 Ma indicating that bedrock cooling ages are younger than the Permian bedrock ages, thus the bedrock was once buried deep enough to be heated $\sim 70^{\circ} \mathrm{C}(\sim 3$ $\mathrm{km}$ ). Over the course of $30 \mathrm{Ma}, 1.6 \mathrm{~km}$ of sediment was exhumed from the range (Hoffman, 2014). The average age of volcanic deposits or exhumed apatite and zircon minerals are youngest in the central region of the Rio Grande Rift and increase toward the rift margins (Hoffman, 2014). The apatite ages from the Guadalupe Mountains studied by Hoffman (2014) are within the same age range as other mountain ranges affected by expansion of the Rio Grande Rift.

The formation ages and cooling ages from previous studies indicate that important climatic or tectonic events contributed to the evolution of the landscape in the Guadalupe Mountains. The next research questions that need to be addressed relate to understanding what processes influenced the shape of the rocks at the surface. The history of climatic, geomorphic, and tectonic processes can be preserved in the regional characteristics of hillslope topography. The properties of underlying bedrock materials control slope morphology, and environmental forces act to modify the slopes (Ritter et al., 2011). Surface exposure dating using in-situ produced cosmogenic radionuclides is a powerful tool to quantify landscape evolution (Gosse 
and Phillips, 2001; Ivy-Ochs and Kober, 2008). Cosmogenic nuclides are produced in minerals close to the surface of the Earth due to nuclear reactions caused by cosmic radiation. The isotopes produced have well known individual isotope half-lives, making it possible to calculate an exposure age with measured concentrations (Lal, 1991; Phillips et al., 2003). Cosmogenic nuclide concentrations increase with greater lengths of exposure at the surface, but decrease with increasing erosion rate (Phillips et al., 2003; Ivy-Ochs and Kober. 2008). Cosmogenic analysis allows one to effectively calculate exposure ages and erosion rates of any rock surface from the Pliocene to the late Holocene depending on the surface preservation and exposure history (IvyOchs and Kober, 2008; Akcar et al., 2009). Normal-fault footwall faces, along with bedrock landforms, glacially polished bedrock surfaces, and landslide bedrock detachment surfaces, can be directly sampled and dated using cosmogenic analysis (Ivy-Ochs and Kober, 2008). This technique is useful to study the landscape in the Guadalupe Mountains, due to the ample bedrock exposures along distinct escarpment features.

The purpose of this study is to understand the geomorphic evolution of the Guadalupe Mountains by surface dating fault-line escarpments. No published cosmogenic study has been completed in the Guadalupe Mountains, and therefore this study is exploratory in nature. The western escarpment, known as the Rim, provides an interesting location to measure how erosion and tectonic processes interact to offer insight into regional climatic, tectonic, and geomorphic conditions (Figure 1). Pairs of bedrock samples collected for cosmogenic analyses from the top and bottom of five different mapped fault lines that make up the Rim (Figure 2) are used to determine the exposure ages and erosion rates in the Guadalupe Mountains. Results from cosmogenic analysis provide understanding of erosional and tectonic processes that shaped the 
current landscape in the Guadalupe Mountains. This study tests hypotheses developed from observations of regional development of the Rio Grande Rift. If surface geomorphology is closely linked to tectonic processes, it is expected that exposure ages will be younger in the northern portion of the range related to evidence of extension propagation along the length of the Rio Grande Rift. Alternatively, younger exposure ages may indicate faster exhumation by geomorphic processes than by tectonic processes.

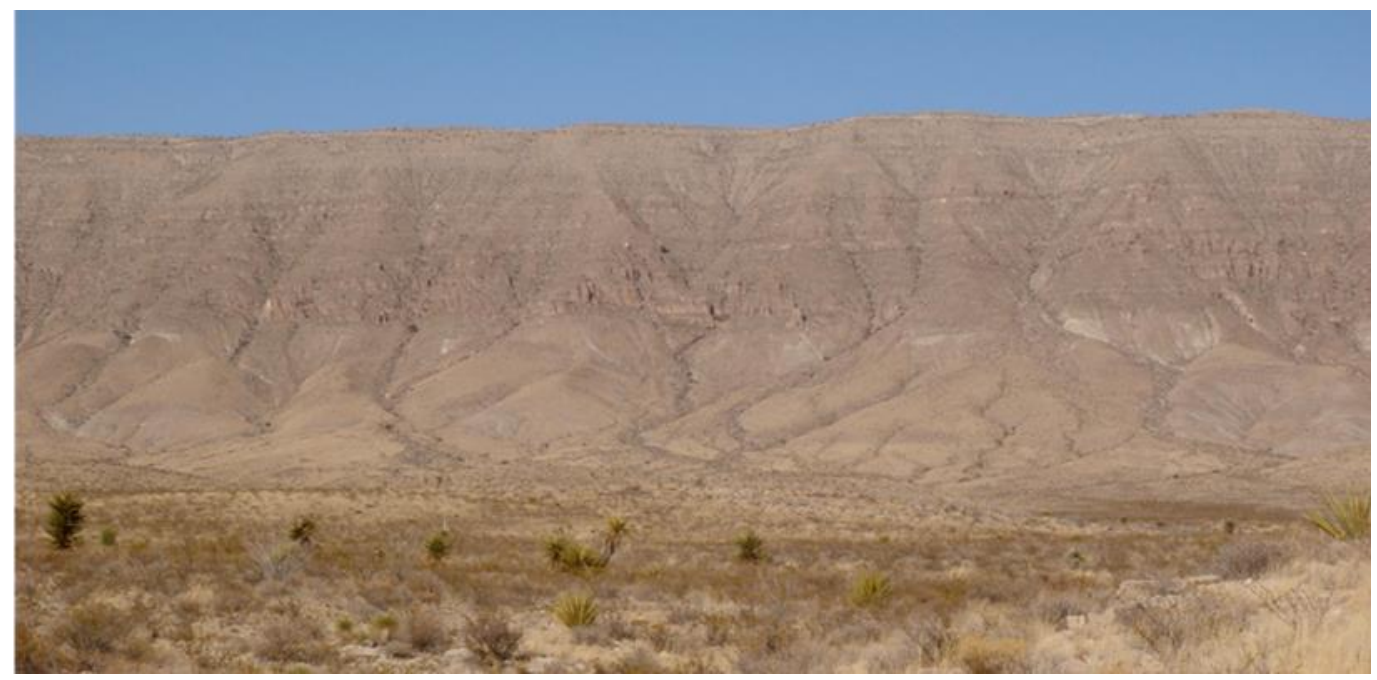

Figure 1. Photo of the Rim (western escarpment) near Dog Canyon. Alluvial fans form the base of the slope (Photo source: Lisa Tranel) 


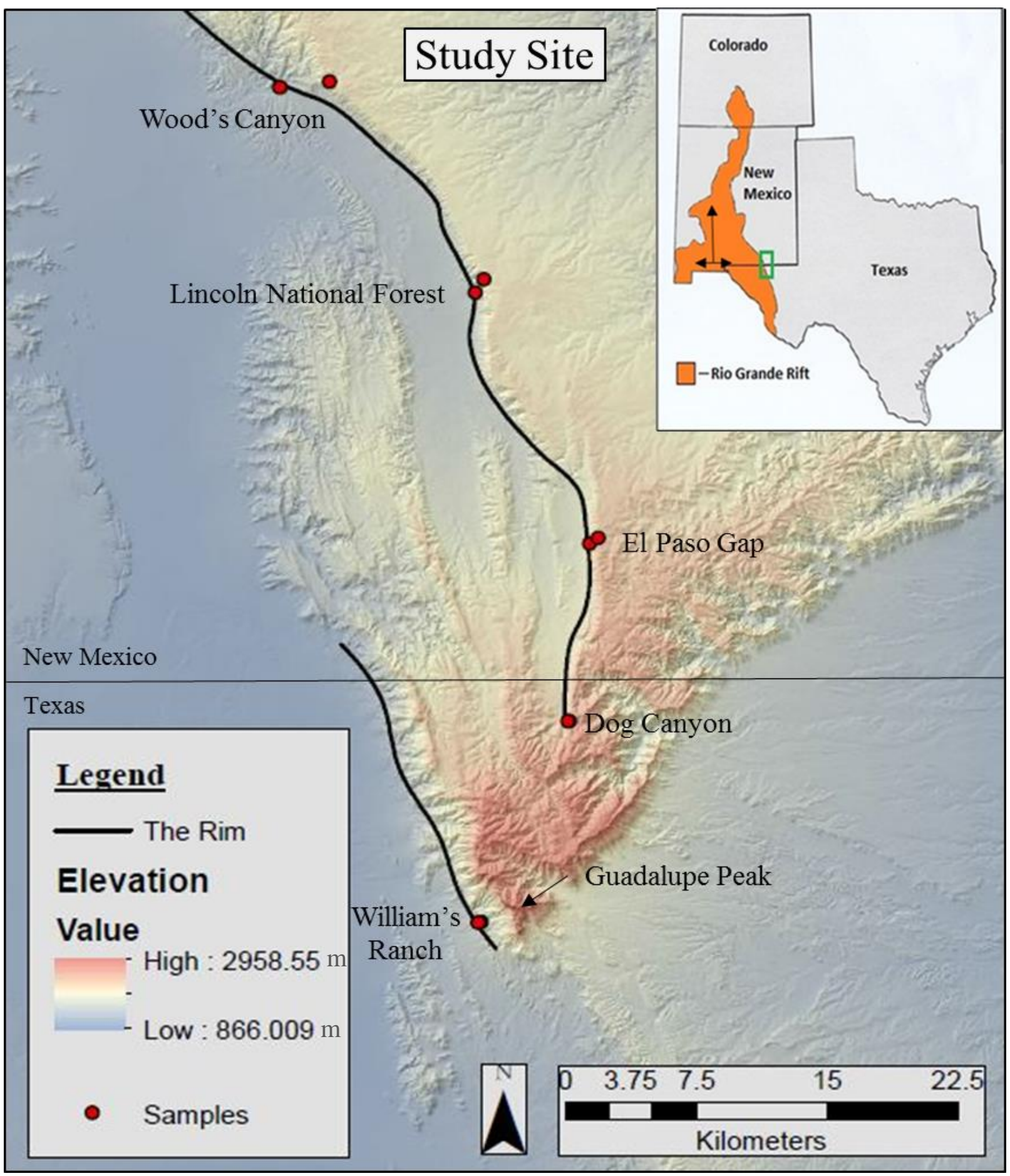

Figure 2. Study site location map. Within the inset, the Rio Grande Rift is orange with arrows to annotate the propagation; the green box represents the location of the Guadalupe Mountains. The main picture illustrates the shape and location of the Guadalupe Mountains with the western escarpment, known as the Rim, traced, and labeled. Samples collected for cosmogenic analysis are plotted across study site. 


\section{Background}

\section{Guadalupe Mountains}

The Guadalupe Mountains are located in the southeastern portion of New Mexico and west Texas and experience semi-arid climate. The range is a limestone tilted fault block that expands like a wedge to the north forming two escarpments on the east and west (King, 1948). The eastern escarpment follows the horseshoe shaped perimeter of the Delaware Basin (King, 1948). The western edge of the tilted fault block forms the western escarpment that slopes toward the Salt Flat Basin and follows the shoulder of the Rio Grande Rift (Keller and Baldridge, 1999). The western escarpment includes the highest peak in Texas, Guadalupe Peak, with a summit almost one mile above the lowest elevation in Salt Flat Basin (King, 1948). The rocks exposure along the western escarpment provide one of the finest cross sections of transition from shallow-water to deep-water deposits, preserving a record of the Permian Period in North America.

During the Permian Period, a shallow sea dominated the region. A reef, in the shape of a horseshoe, formed around the sea that produced massive beds of limestone known as the Capitan Formation (Hill, 2000) (Figure 3). The Capitan Formation grew steadily upward around the Delaware Basin, and a thick sequence of siliciclastic sediments were deposited deep within the basin. As a result, interbedded carbonate, siliciclastic, and evaporate layers were deposited on the shallow lagoon shelf behind the reef (Figures 4 and 5) (Scholle et al., 1992, Hill, 2000). 


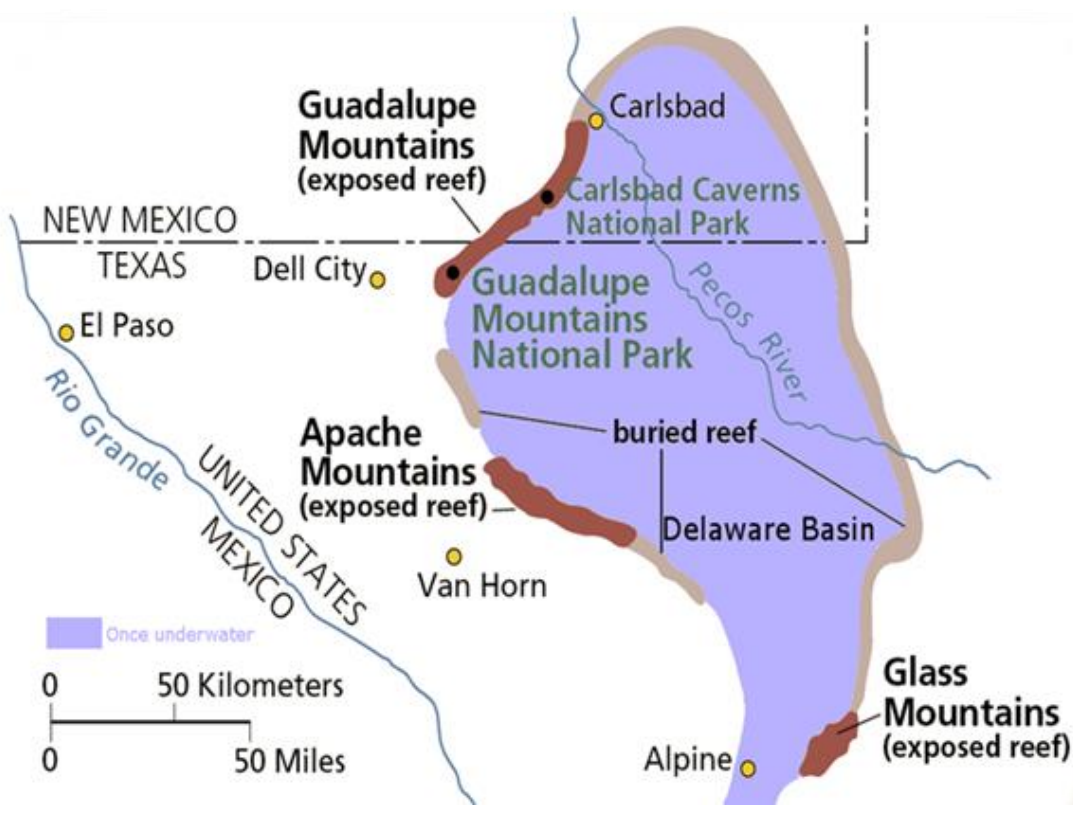

Figure 3. Location of the Delaware Basin and exposed Capitan Reef complex (Source: Keller Lynn, 2008) 


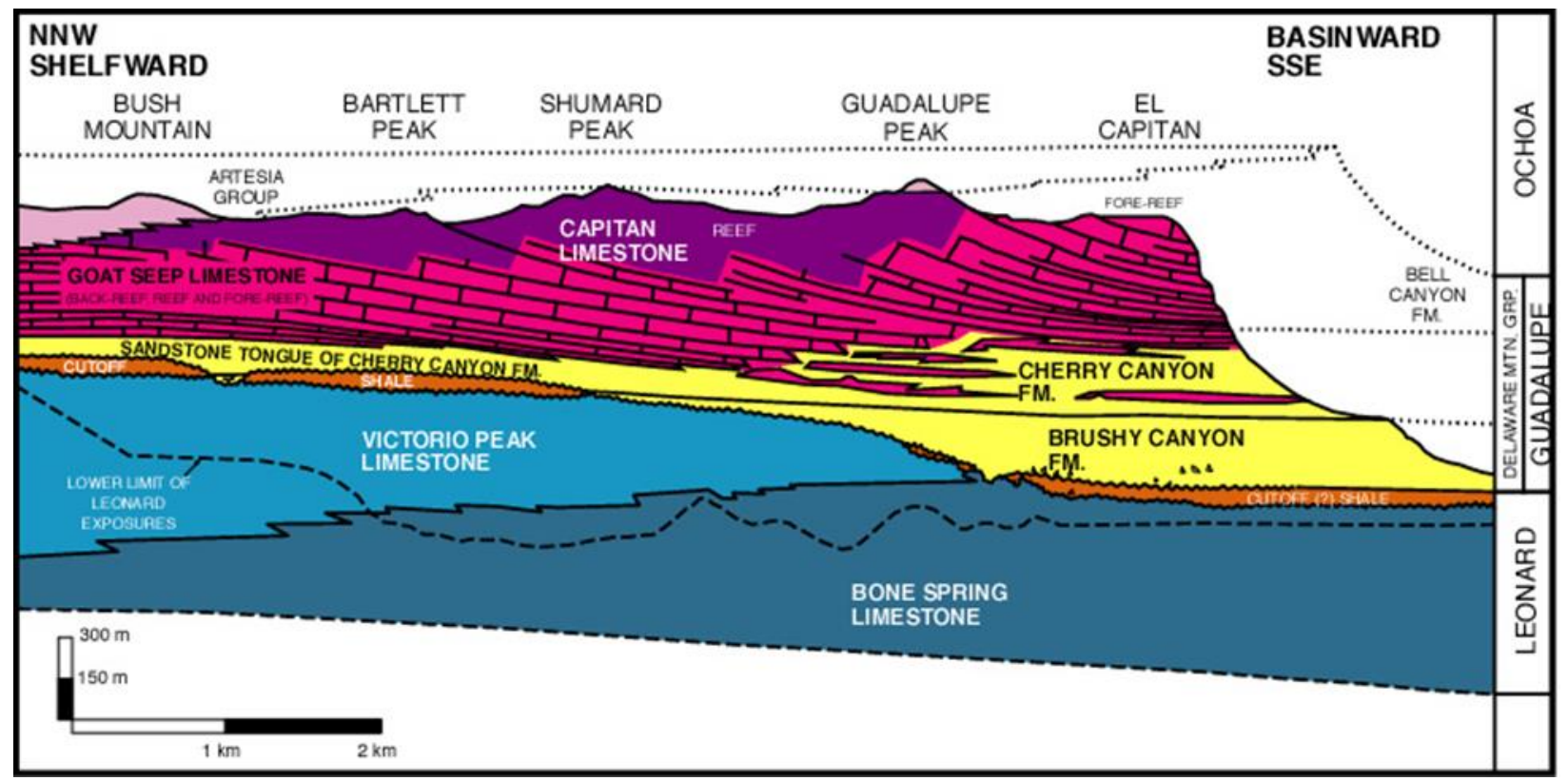

Figure 4. Stratigraphic cross section of the Guadalupe Mountains (Source: King, 1948 and Keller Lynn, 2008) 


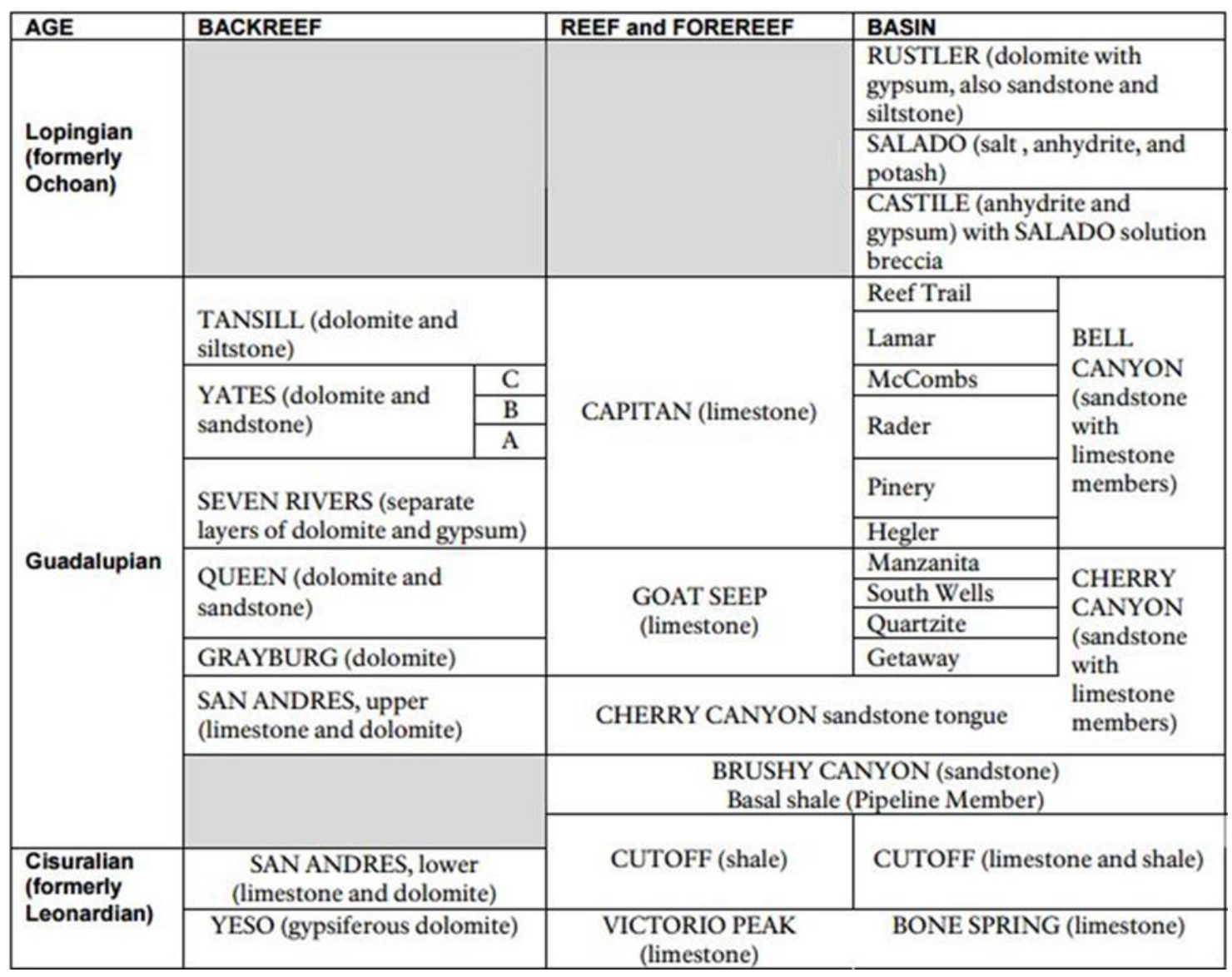

Figure 5. Permian rock formations in stratigraphic provinces (Source: Keller Lynn, 2008).

Following carbonate sedimentation and deposition of evaporates due to increasing aridity, the restriction of water exchange with the open ocean led to regional evaporative drawdown of water levels due to global sea level drop (Scholle et al., 1992; Hill, 2000). This resulted in exposure and weathering of the shelf, coupled with sedimentation of thick evaporates in the basin. Eventually, after filling the Delaware Basin, evaporates were also deposited across adjacent shelf areas and were composed predominately of calcium sulphate, halite, and sylvite. 
These minerals formed the regional seal that precluded extensive water influx into the basin during the subsequent 200 million years of post-depositional history (Scholle et al., 1992). The deposition of the Upper Permian evaporates and associated red beds was followed by a $200 \mathrm{Ma}$ interval during which the region was part of a stable, non-depositional province. Less than one kilometer of non-marine sediment was deposited across the region during the Mesozoic as a result of deltaic, lacustrine, and fluvial environments (Scholle et al., 1992; Hill, 2000). The long interval of quiescence was interrupted by uplift, a process that began with the late Cretaceous Laramide orogeny and continued during the middle to late Tertiary Basin and Range block faulting (Scholle et al., 1992). Uplifting events eventually led to the exposure of the Permian section in the Guadalupe Mountains, by exhuming rock and depositing sediments in adjacent basins (Scholle et al., 1992).

\section{Rio Grande Rift}

The Rio Grande Rift is a Cenozoic continental rift zone that follows the topographic crest of the southern Rocky Mountains (Buck, 1991; Keller and Baldridge, 1999). The southern portion of the rift is physiographically similar to the adjacent Basin and Range province, yet can be distinguished by a variety of geological and geophysical features; including basin size and depth, evidence of Quaternary tectonism, as well as crustal thinning (Keller and Baldridge, 1999; Moucha, 2008). Rifting has been uninterrupted with two periods of extension since its initiation $30 \mathrm{Ma}$ and the timing of extension varies along the rift (Keller and Baldridge, 1999). The first period of extension took place 30 to $20 \mathrm{Ma}$ and a second took place $15 \mathrm{Ma}$ to present (Gao et al., 2004). The first period of extension began due to forces acting on the western edge of the North 
American plate (Keller and Baldridge, 1999). The second phase of extension began in a backarc setting during east-dipping subduction of the Farallon Plate beneath the North American Plate (Keller and Baldridge, 1999).

The Rio Grande Rift is a north-trending and northward-narrowing zone of lithospheric extension that follows the older Laramide orogenic event (Keller and Baldridge, 1999). The upper crust is a series of north trending en-echelon basins and adjacent normal fault escarpments (Barrow and Keller, 1994). The rift is situated at the zone of transition between the abnormally thin continental crust of the Basin and Range province averaging slightly more than $30 \mathrm{~km}$ and the western Great Plains, with crustal thickness ranging between 45-55 km (Ramberg et al., 1978, Keller and Baldridge, 1999, Gao et al., 2004).

\section{Geomorphology of normal faults scarps and slopes}

When the lithosphere is under extension, the brittle upper crust breaks and is displaced along normal faults (Leeder and Jackson, 1993). Extensional landscapes evolve by erosional and depositional modification of slopes produced by normal faults. Normal fault asymmetry produces steep footwall slopes on eroding fault faces, and long, gentle hanging wall slopes in adjacent sedimentary basins (Leeder and Jackson, 1993). In extensional settings, $80 \%$ of the movement along the footwall is because of subsidence of the hanging wall, primarily due to accumulation of sediments (Byrd et al., 1994).

Once a fault scarp forms, erosion degrades it (Wallace, 1977). The degradation of fault scarps is understood by a transport law in which the rate of change of elevation on a slope varies with cross-section position. Erosion lowers the upper footwall slope, and the resulting sediments 
are deposited at the base of the slope over the hanging wall (Nash, 1980; Hanks et al., 1984; Turko and Knuepfer, 1991). The relative resistance of earth's materials influences the character of the slope that develops (Ritter et al., 2011). In the process of change, the slope of the original fault scarp is replaced by one controlled by erosional processes (Wallace, 1977; Nash, 1980). In the early stages of slope degradation, the dominant erosional process is gravity spalling from the free face and accompanying accumulation of debris at the scarp base. As time passes, water erosion becomes the dominant process, and the slope angle declines (Wallace, 1977). Gullies cut into the top of the scarp, and drainage networks propagate to form a central drainage divide (Leeder and Jackson, 1993).

The transformation of rock into unconsolidated debris is the geomorphic contribution of weathering and soil-forming processes, and is the beginning of the sedimentary transport processes of creating a slope. Whether the debris produced by weathering will resist erosion and become part of the regolith depends on the balance between the internal resistance of the rock and the magnitude of external forces acting on the rock (Ritter et al., 2011). The profiles of natural slopes formed primarily by erosional processes are regarded as reflections of major geomorphic factors including: climate, rock type, structure, time, and process (Ritter et al., 2011).

In semi-arid climates, slopes are weathering limited, meaning the rate of soil and regolith production is lower than the rate of removal by erosion, and are controlled by the mass strength of the parent rock (Ritter et al., 2011). Weathering limited slopes usually evolve by parallel retreat, which is characterized by the maintenance of constant angles on the steepest part of the slope (Ritter et al., 2011). The shape of weathering-limited profiles is determined by the 
character of the parent rock (Ritter et al., 2011). In environments with humid-temperature conditions and continuous vegetation, transport-limited slopes form because the rate of weathering is more rapid than erosion. Slopes produced under this regime can develop on any unconsolidated parent material regardless of the environment (Ritter et al., 2011).

\section{Cosmogenic Nuclides}

Cosmogenic nuclides build-up predictably with time in minerals exposed to cosmic rays (Ivy-Ochs and Kober, 2008). Therefore, measuring their concentrations allows determination of how long rocks or sediments have been exposed (Lal, 1991; Gosse and Phillips, 2001).

Cosmogenic nuclides, including ${ }^{10} \mathrm{Be},{ }^{14} \mathrm{C},{ }^{26} \mathrm{Al}$, and ${ }^{36} \mathrm{Cl}$, are products of interactions between cosmic radiation with a variety of target atoms within mineral lattices (Table 1) (Lal, 1991; Akcar et al., 2009). The production of nuclides decreases exponentially with depth only accumulating in the top two meters of the surface, therefore making cosmogenic nuclides a useful tool for measuring rates of erosion and length of exposure (Lal, 1991; Gosse and Phillips, 2001). Because the cosmic ray flux decreases exponentially with depth below the surface, the accumulated cosmogenic nuclide concentration in the mineral grain records the speed with which that grain has been unearthed; slower erosion rates imply longer exposure times near the surface, and thus higher concentrations (Granger et al., 1996). Cosmogenic ${ }^{36} \mathrm{Cl}$ is mainly applied to carbonate rocks $\left(\mathrm{CaCO}_{3}\right)$, and is produced by several mechanisms, these include: fast neutron spallation on ${ }^{40} \mathrm{Ca}$, absorption of epithermal and thermal neutrons by ${ }^{35} \mathrm{Cl}$, and the capture of slow negative muons on ${ }^{40} \mathrm{Ca}$ (Akcar et al., 2009). Cosmogenic ${ }^{10} \mathrm{Be}$ is extracted from the mineral quartz $\left(\mathrm{SiO}_{2}\right)$ and is produced by three mechanisms: high-energy spallation, negative 
muon capture, and fast muon interactions with ${ }^{18} \mathrm{O}$ (Balco et al., 2008). Accelerator mass spectrometry (AMS) is used to determine concentrations of long-lived radionuclides by measuring ratios relative to a standard material (Ivy-Ochs and Kober, 2008).

TABLE 1. LIST OF COSMOGENIC NUCLIDES WITH RESPECTIVE HALF-LIFE IN TARGET MINERALS (MODIFIED FROM: Lal, 1991)

\begin{tabular}{|c|c|c|c|c|c|c|}
\hline Nuclide & Half-life & $\begin{array}{c}\text { Other } \\
\text { Isotopes }\end{array}$ & $\begin{array}{l}\text { Suitable } \\
\text { minerals }\end{array}$ & $\begin{array}{c}\text { Target } \\
\text { elements }\end{array}$ & $\begin{array}{l}\text { Production } \\
\text { rate (atoms } \\
\left.\quad \mathrm{g}^{-1} \mathrm{yr}^{-1}\right)\end{array}$ & $\begin{array}{l}\text { Applicable } \\
\text { time range }\end{array}$ \\
\hline${ }^{10} \mathrm{Be}$ & $\begin{array}{c}1.5 \\
\text { million } \\
\text { years }\end{array}$ & ${ }^{9} \mathrm{Be}$ & Quartz & $\begin{array}{l}\text { Oxygen }(\mathrm{O}) \text {, } \\
\text { Silicon }(\mathrm{Si})\end{array}$ & 5 & $\begin{array}{c}\text { Several } \\
\text { million years }\end{array}$ \\
\hline${ }^{14} \mathrm{C}$ & $\begin{array}{l}5730 \\
\text { years }\end{array}$ & ${ }^{12} \mathrm{C},{ }^{13} \mathrm{C}$ & Quartz & Oxygen (O) & 16 & $\begin{array}{c}\text { Up to } 20,000 \\
\text { years }\end{array}$ \\
\hline${ }^{26} \mathrm{Al}$ & $\begin{array}{c}0.7 \\
\text { million } \\
\text { years }\end{array}$ & ${ }^{27} \mathrm{Al}$ & Quartz & Silicon (Si) & 31 & $\begin{array}{l}\text { Up to several } \\
\text { million years }\end{array}$ \\
\hline${ }^{36} \mathrm{Cl}$ & $\begin{array}{c}0.3 \\
\text { million } \\
\text { years }\end{array}$ & ${ }^{35} \mathrm{Cl},{ }^{36} \mathrm{Cl}$ & $\begin{array}{l}\text { All types of } \\
\text { rocks }\end{array}$ & $\mathrm{Ka}, \mathrm{Ca},{ }^{35} \mathrm{Cl}$ & $\begin{array}{c}10 \text { (granite) } \\
20(\text { limestone })\end{array}$ & $\begin{array}{c}\text { Up to } 1 \\
\text { million years }\end{array}$ \\
\hline${ }^{3} \mathrm{He}$ & Stable & ${ }^{4} \mathrm{He}$ & $\begin{array}{l}\text { Olivine, } \\
\text { Pyroxene }\end{array}$ & Many & 120 & $\begin{array}{c}\text { To millions } \\
\text { of years }\end{array}$ \\
\hline${ }^{21} \mathrm{Ne}$ & Stable & $\begin{array}{l}{ }^{20} \mathrm{Ne}, \\
{ }^{22} \mathrm{Ne}\end{array}$ & $\begin{array}{l}\text { Quartz, } \\
\text { olivine, } \\
\text { pyroxene }\end{array}$ & $\mathrm{Si}, \mathrm{Mg}$ & 20 & $\begin{array}{c}10 \mathrm{~s} \text { of } 1000 \mathrm{~s} \\
\text { to millions of } \\
\text { years }\end{array}$ \\
\hline
\end{tabular}




\section{CHAPTER II: METHODOLOGY}

Ten bedrock samples, including seven of limestone $\left({ }^{36} \mathrm{Cl}\right)$ and three of sandstone $\left({ }^{10} \mathrm{Be}\right)$ were collected throughout the Guadalupe Mountains along the Rim in order to understand the geomorphic history of the region. Three (GMLH1302, GMLH1305, WC-01) of the ten samples were collected previously, and will not be described in methods. The details of collection for GMLH1302, GMLH1305, and WC-01 can be found in Hoffman (2014) Master's Thesis. The following sections outline the methods for retrieving samples in the field, preparing samples for cosmogenic analysis, and calculating exposure ages and erosion rates with tools including CRONUS-Earth online calculator, ArcGIS, and MATLAB.

\section{Field work}

In March of 2016, my field assistants and I collected seven samples from fault escarpments along the Rim of the western margin of the Guadalupe Mountains. We collected samples from the top and bottom of fault escarpments at three different locations based on accessibility and exposed bedrock at the surface. In addition, a sample was collected from the top of Wood's Canyon because Hoffman (2014) already collected the bottom sample. We also made sure to choose in-place bedrock that did not have obstructions that would hinder cosmic ray travel (Ivy-Ochs and Kober, 2008).

At each sample location, we recorded the following information needed to calculate exposure ages; these data include: longitude, latitude, elevation, strike, and dip (Table 2). A laser range finder measured inclination $\left(^{\circ}\right)$ and azimuth $\left(^{\circ}\right)$ every $20^{\circ}$ to the horizon from each sample position to calculate a shielding factor. The shielding factor is a variable required to 
calculate the exposure age of the samples, and will be discussed in more detail in a later section. We described each rock, weathering conditions to have more notes on the surface, and took photos of each sample location and surrounding landscape at each site (Figure 6 and Table 3).

TABLE 2. FIELD DATA COLLECTED IN MARCH 2013, 2016, AND NOVEMBER 2014

\begin{tabular}{|c|c|c|c|c|c|c|}
\hline Sample ID & $\begin{array}{l}\text { Latitude } \\
\text { (DD) }\end{array}$ & $\begin{array}{l}\text { Longitude } \\
\text { (DD) }\end{array}$ & $\begin{array}{l}\text { Elevation } \\
\text { (m) }\end{array}$ & $\begin{array}{l}\text { Strike/Dip } \\
\left({ }^{\circ}\right)\end{array}$ & $\begin{array}{c}\text { Position } \\
\text { on } \\
\text { Scarp }\end{array}$ & Location \\
\hline \multicolumn{7}{|c|}{${ }^{36} \mathrm{Cl}$ Samples (Limestone) } \\
\hline GMAH-01 & 31.9878 & -104.865 & 2154.00 & $142 / 41$ & Top & Dog Canyon \\
\hline GMAH-03 & 31.9899 & -104.828 & 2120.40 & $120 / 24$ & Bottom & Dog Canyon \\
\hline GMAH-04 & 31.8822 & -104.881 & 1627.20 & $34 / 19$ & Top & $\begin{array}{c}\text { William’s } \\
\text { Ranch }\end{array}$ \\
\hline GMAH-06 & 31.8819 & -104.883 & 1546.00 & $143 / 5$ & Bottom & $\begin{array}{l}\text { William's } \\
\text { Ranch }\end{array}$ \\
\hline GMAH-07 & 31.3329 & -104.973 & 1868.70 & $230 / 6$ & Top & $\begin{array}{l}\text { Wood's } \\
\text { Canyon }\end{array}$ \\
\hline GMAH-08 & 32.0849 & -104.815 & 1807.50 & $165 / 46$ & Bottom & El Paso Gap \\
\hline WC-01 & 32.3337 & -104.997 & 1381.70 & $126 / 31$ & Bottom & $\begin{array}{l}\text { Wood's } \\
\text { Canyon }\end{array}$ \\
\hline \multicolumn{7}{|c|}{${ }^{10}$ Be Samples (Sandstone) } \\
\hline GMLH1302 & 32.2268 & -104.879 & 1835.00 & $176 / 9$ & Top & $\begin{array}{c}\text { Lincoln Nat'l } \\
\text { Forest }\end{array}$ \\
\hline GMLH1305 & 32.2195 & -104.884 & 1607.44 & $107 / 16$ & Bottom & $\begin{array}{c}\text { Lincoln Nat'l } \\
\text { Forest }\end{array}$ \\
\hline GMAH-09 & 32.0879 & -104.809 & 2082.00 & $201 / 4$ & Top & El Paso Gap \\
\hline
\end{tabular}




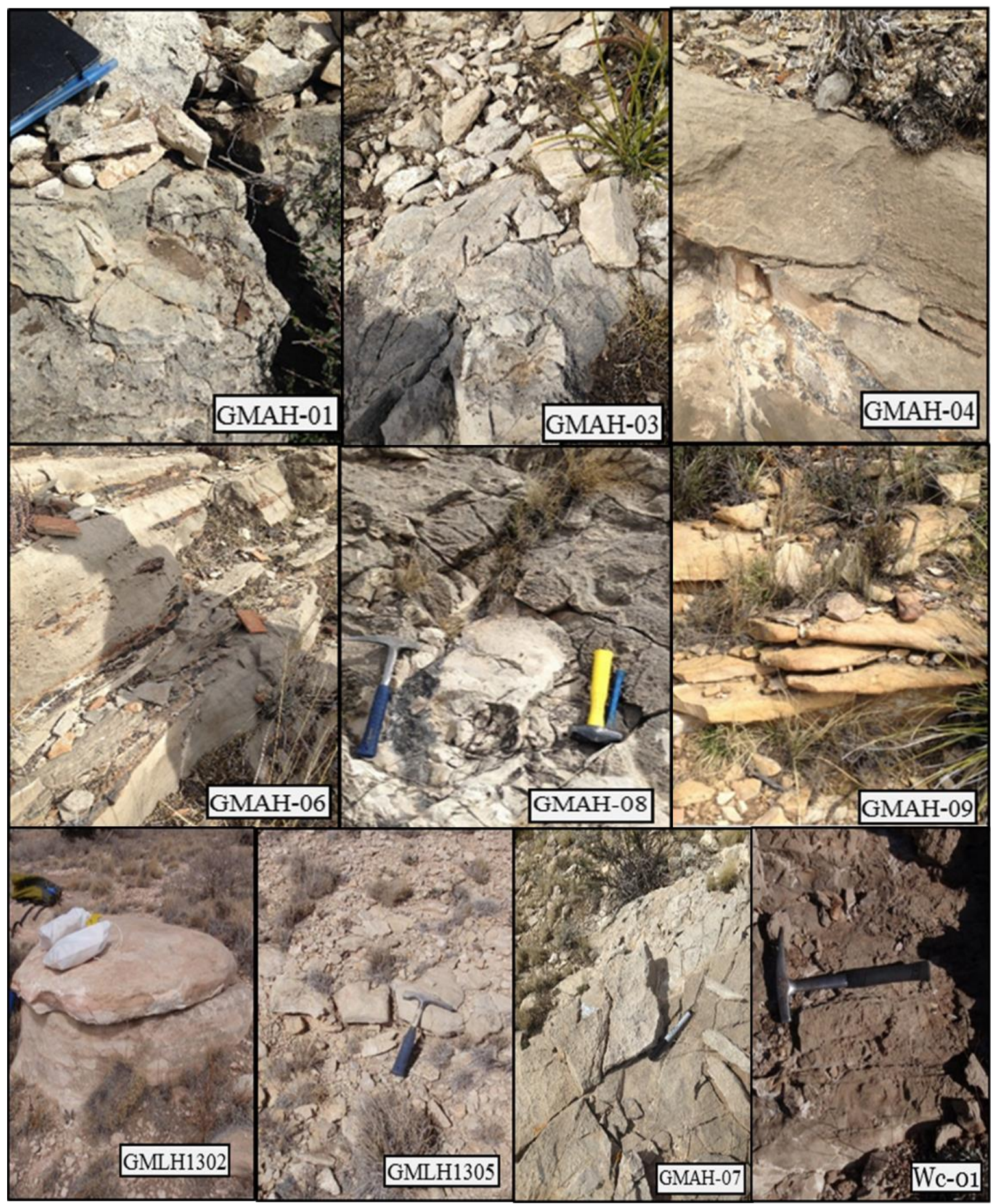

Figure 6. Images of samples collected for cosmogenic analysis. Corresponding weathering and rock descriptions can be found in table 3. Samples with label beginning with "GMAH" were collected in March 2016. The remaining samples were collected in March 2013 or November 2014. 


\begin{tabular}{|c|c|c|c|c|}
\hline Sample ID & $\begin{array}{l}\text { Location } \\
\text { on Scarp }\end{array}$ & $\begin{array}{l}\text { Elevation } \\
\text { (m) }\end{array}$ & Rock Description & Weathering Description \\
\hline GMAH-01 & Top & 2154 & $\begin{array}{l}\text { Collected from the } \\
\text { Carlsbad Formation (Pcb). } \\
\text { Gray fossiliferous } \\
\text { limestone }\end{array}$ & $\begin{array}{l}\text { Weathered iron oxide present } \\
\text { around chert bands and nodules. } \\
\text { Weathered face was smooth and } \\
\text { holey with brown coloring, the } \\
\text { fresh face was dark gray. }\end{array}$ \\
\hline GMAH-03 & Bottom & 2120.4 & $\begin{array}{l}\text { Collected from the Goat } \\
\text { Seep Formation (Pgs). } \\
\text { Gray fossiliferous } \\
\text { limestone with viens of } \\
\text { calcite throughout. }\end{array}$ & $\begin{array}{l}\text { Weathered iron oxide present } \\
\text { around chert bands and nodules. } \\
\text { face had sharp dissolution points } \\
\text { throughout the surface and was red } \\
\text { brown in color, the fresh face was } \\
\text { dark gray }\end{array}$ \\
\hline GMAH-04 & Top & 1546 & $\begin{array}{l}\text { Collected from the Bone } \\
\text { Spring Formation }(\mathrm{Pbl}) . \\
\text { Dark gray, thin-bedded } \\
\text { cherty limestone. }\end{array}$ & $\begin{array}{l}\text { Weathered face had sharp } \\
\text { dissolution points throughout the } \\
\text { surface and was brown in color, the } \\
\text { fresh face was gray. }\end{array}$ \\
\hline GMAH-06 & Bottom & 1627.2 & $\begin{array}{l}\text { Collected from the Bone } \\
\text { Spring Formation }(\mathrm{Pbl}) . \\
\text { Dark gray, thin-bedded } \\
\text { cherty limestone }\end{array}$ & $\begin{array}{l}\text { Weathered face had sharp } \\
\text { dissolution points throughout the } \\
\text { surface and was brown in color, the } \\
\text { fresh face was gray. }\end{array}$ \\
\hline GMAH-08 & Bottom & 2082 & $\begin{array}{l}\text { Collected from the } \\
\text { Artesian Group (Pat). } \\
\text { Brown quartz sandstone } \\
\text { with calcite cement. }\end{array}$ & $\begin{array}{l}\text { Lichen was present on the } \\
\text { weathered face of the rock. } \\
\text { Weathered face was red brown, } \\
\text { fresh face was light brown }\end{array}$ \\
\hline GMAH-09 & Top & 1807.5 & $\begin{array}{l}\text { Collected from the Queen } \\
\text { and Grayburg Formation } \\
\text { (Pqg). Gray dolomite. }\end{array}$ & $\begin{array}{l}\text { Weathered surface was vuggy and } \\
\text { jointing was present throughout the } \\
\text { surface. The weathered face was } \\
\text { brown, and the fresh face was pale } \\
\text { orange to gray. }\end{array}$ \\
\hline GMLH1302 & Top & 1835 & $\begin{array}{l}\text { Collected from the } \\
\text { Artesian Group (Pat). } \\
\text { Brown quartz sandstone } \\
\text { with calcite cement. }\end{array}$ & $\begin{array}{l}\text { The weathered face was gray, and } \\
\text { the fresh face was brown. }\end{array}$ \\
\hline GMLH1305 & Bottom & 1607.4 & $\begin{array}{l}\text { Collected from the San } \\
\text { Andres (Psa). Brown } \\
\text { quartz sandstone with } \\
\text { calcite cement. }\end{array}$ & $\begin{array}{l}\text { The weathered face was gray, and } \\
\text { the fresh face was brown. }\end{array}$ \\
\hline
\end{tabular}

(Table Continues) 


$\begin{array}{ccccc}\begin{array}{c}\text { GMAH- } \\ 07\end{array} & \text { Top } & \text { 1868.7 } & \begin{array}{c}\text { Collected from the San } \\ \text { Andres Formation (Psa). } \\ \text { Gray fossiliferous limestone }\end{array} & \begin{array}{c}\text { The weathered face had sharp } \\ \text { dissolution points and vuggy surface. } \\ \text { The weathered face was gray, and the } \\ \text { fresh face was brown. }\end{array} \\ \text { WC-01 } & \text { Bottom } 1381.7 \quad \begin{array}{c}\text { Collected from the San } \\ \text { Andres Formation (Psa). } \\ \text { Gray fossiliferous limestone }\end{array} & \begin{array}{r}\text { The weathered face had sharp } \\ \text { dissolution points and vuggy surface. } \\ \text { The weathered face was gray, and the } \\ \text { fresh face was brown. }\end{array}\end{array}$

After finding proper sampling surfaces of in-place bedrock with minimal obstructions, we chiseled bedrock samples out of the top 2-5 cm of the outcrops. Once the sample was removed from the outcrop, the sample was labeled with a ' $\mathrm{T}$ ' for the top face of the rock that was exposed, and a ' $\mathrm{S}$ ' for the side facing the surface of the rock. We labeled the samples for future reference when crushing the samples at Illinois State University (ISU). We chronologically labeled the samples in order of collection, starting with GMAH-01ending with GMAH-09. All samples were placed in their own rock bag, labeled with their respective name, sample location, and date.

\section{Cosmogenic Analysis}

\section{Physical Treatment}

The physical preparation of collected bedrock samples continued at ISU, where samples were broken down into sediments that were then sent to Purdue University's PRIME (Purdue Rare Isotope Measurement) laboratory for chemical treatment and cosmogenic analysis with AMS detection. The first step in physical preparation is to trim samples thicker than five $\mathrm{cm}$. Nuclide production rates decrease exponentially after a distance of $5 \mathrm{~cm}$ from the surface, 
therefore nuclides accumulate more efficiently in the top $5 \mathrm{~cm}$ of the surface (Gosse and Phillips, 2001). We measured $5 \mathrm{~cm}$ of thickness from the top surface to confirm that the rocks analyzed for cosmogenic nuclides have the optimum concentration. Rocks were cut to $5 \mathrm{~cm}$ with a rock saw. The surface pieces were crushed with the rock grinder and sieved to $250-500 \mu \mathrm{m}$. All equipment used to crush and sieve the samples were blown clean with an air compressor to ensure no cross contamination between samples. The sieved grains were washed with water to remove fine particles and rinsed with acetone. Finally, 200 grams of the prepared $250-500 \mu \mathrm{m}$ grains from each sample were sent to Purdue University PRIME lab for chemical treatment and AMS detection.

\section{Chemical Treatment}

At Purdue University’s PRIME lab, samples underwent chemical preparation that resulted in the isolation of specific isotopes, ${ }^{36} \mathrm{Cl}$ and ${ }^{10} \mathrm{Be}$, which were measured with AMS. There are various steps in the chemical process of separating and isolating the specific isotopes. The following sections describe chemical treatments for ${ }^{10} \mathrm{Be}$ and ${ }^{36} \mathrm{Cl}$.

\section{${ }^{10} \mathrm{Be}$}

Samples processed for ${ }^{10} \mathrm{Be}$ were first leached in $6 \mathrm{~N} \mathrm{HCl}$ and successively etched in a $1 \% \mathrm{HF} / \mathrm{HNO}_{3}$ mixture at $80^{\circ} \mathrm{C}$ in an ultrasonic bath overnight. The etching in the $\mathrm{HF} / \mathrm{HNO}_{3}$ mixture purified the quartz grains and eliminated atmospheric ${ }^{10} \mathrm{Be}$ (Nishiizumi et al., 1993; Palumbo et al., 2015). The purified quartz samples were spiked with approximately $0.27 \mathrm{mg}$ of ${ }^{9} \mathrm{Be}$ in a carrier solution prepared from beryl and dissolved in $\mathrm{HF} / \mathrm{HNO}_{3}$ (Nishiizumi et al., 1993, 
Balco et al., 2008, Palumbo et al., 2015). After drying, fluorides were expelled with $\mathrm{H}_{2} \mathrm{SO}_{4}$ (Federici et al., 2011). Iron was removed by anion exchange in 9 N HCL (Federici et al., 2011). Calcium, magnesium, manganese, and alkali metals were removed during precipitation with $\mathrm{NH}_{4} \mathrm{OH}$ (Ivy-Ochs and Kober, 2008). Beryllium was isolated from the resulting hydroxide gel by cation exchange in a $0.4 \mathrm{M}$ oxalic acid solution (Federici et al., 2011). Beryllium hydroxide was oxidized at $1100^{\circ} \mathrm{C}$, mixed with $\mathrm{Nb}$, and packed into stainless steel holders for AMS detection (Nishiizumi et al., 1993; Ivy-Ochs and Kober, 2008; Federici et al., 2011).

\section{${ }^{36} \mathrm{Cl}$}

Samples processed for ${ }^{36} \mathrm{Cl}$ were first leached in $2 \mathrm{M} \mathrm{HNO}_{3}$ twice, rinsed with ultrapure water $(18.2 \mathrm{M} \Omega \mathrm{cm})$ and placed in an ultrasonic bath overnight to release non-in-situ produced ${ }^{36} \mathrm{Cl}$ (meteoric) (Phillips et al., 1986; Lal, 1991; Zreda and Noller, 1998). About $1.0 \mathrm{mg}$ of pure

${ }^{35} \mathrm{Cl}$ spike was added to the leached samples, and samples were dissolved in $\mathrm{HNO}_{3}$ again overnight. $\mathrm{AgNO}_{3}$ was added to precipitate $\mathrm{AgCl}$, which is rinsed in deionized water and purified with $\mathrm{BaSO}_{4}$ (Zreda and Noller, 1998). Sulfur was omitted by the precipitation of $\mathrm{BaSO}_{4}$ because ${ }^{36} \mathrm{~S}$ interferes with ${ }^{36} \mathrm{Cl}$ during AMS measurement (Akcar et al., 2009). From purified $\mathrm{AgCl}$, precipitated ${ }^{36} \mathrm{Cl}$ is packed into stainless steel cathodes and measured by AMS. ${ }^{36} \mathrm{Cl}$ analysis requires data form the major elements that make up the rock sample. This is due to the nature of formation of ${ }^{36} \mathrm{Cl}$; in limestone the isotopes form inside the calcium nucleus. If the limestone has undergone any diagenesis to replace the calcium with magnesium, this would hinder the production of the ${ }^{36} \mathrm{Cl}$ isotopes because they do not form from the interaction of 
magnesium. Bulk rock and major element data were determined by X-ray fluorescence at ActLabs in Ontario, Canada.

\section{Calculations}

\section{Shielding Factors}

When analyzing bedrock samples for cosmogenic nuclide concentrations, it is important to take into account any type of topographic obstruction that would shield cosmic rays from the sample (Balco et al., 2008). The inclination and azimuth to features on the horizon, strike, dip, latitude, and longitude data were organized, formatted, and input into CRONUS-Earth online calculator (http://hess.ess.washington.edu/math/general/skyline_input.php) (See Appendix Table 1). The online calculator generated a shielding factor for each sample collected (Tables $4 \& 6$ ). The generated values are used to calculate the exposure ages and erosional rates for each sample.

\section{ArcGIS}

Data were spatially analyzed with ArcGIS, a geographic information system with valuable terrain and three-dimensional tools that model the earth's surface. Data points collected from a GPS device during field work were downloaded as a shapefile into ArcMap and projected to UTM 13N. Ten meter digital elevation models (DEM) data were downloaded from nationalmap.gov, then uploaded into ArcMap, projected to UTM 13N, mosaicked together and clipped to the study site. Hillshade analysis on the clipped DEM provided a basemap to represent the landscape relevant to this project. 
Cross sections of the escarpments between top and bottom sample sites were generated using a model builder that created a line of points with distance and elevation values. Cross section lines were drawn along the fault escarpments, and contour lines were produced. The cross section and contour lines were intersected to create a point wherever two lines crossed. The attribute table from the resulting point layer was exported to excel, and organized into graphs. The distances along the line were plotted against elevation to produce the profile of the sampled escarpment.

The geology map was downloaded geologic map data for New Mexico and Texas states on Nationalmap.org. Once downloaded, the maps were projected to UTM 13N, and clipped to the study site. Attribute tables were combined using field calculator to join common elements. Rock formations that were sampled were made into a geologic column with rock descriptions.

\section{Exposure Age}

Apparent cosmogenic ${ }^{10} \mathrm{Be}$ and ${ }^{36} \mathrm{Cl}$ surface exposure ages were calculated using CRONUS-Earth software (Marrero et al., 2015). ${ }^{10} \mathrm{Be}$ and ${ }^{36} \mathrm{Cl}$ are calculated with different values due to the nature of the isotope formation. The following sections are the methods for calculating exposure ages for ${ }^{10} \mathrm{Be}$ and ${ }^{36} \mathrm{Cl}$.

${ }^{10} \mathbf{B e}$

Apparent cosmogenic ${ }^{10} \mathrm{Be}$ surface exposure ages were calculated using ${ }^{10} \mathrm{Be}-{ }^{26} \mathrm{Al}$ exposure age calculator, version 2.3 (hess.ess.washington.edu). The online calculator is based on MATLAB software that has built in codes accounting for physical constants and input 
parameters used throughout the calculation (Balco et al., 2008). The effective attenuation length for production by high-energy spallation is $160 \mathrm{~g} / \mathrm{cm}^{2}$ for this calculator (Balco et al., 2008, Gosse and Phillips, 2001). The decay constant for ${ }^{10} \mathrm{Be}$ is $4.62 \times 10^{-7} \mathrm{yr}^{-1}$ (Gosse and Phillips, 2001).

Fifteen observational and calculated values for each sample were formatted for the online calculation (See Appendix Table 4). Input observational values included sample name, latitude, longitude, elevation, elevation flag, sample thickness, density, ${ }^{10} \mathrm{Be}$ standardization and erosion rate. Input calculated values included shielding correction, ${ }^{10} \mathrm{Be}$ concentration and uncertainty. Results generated include exposure age (yr.), external uncertainty (yr.) and production rate for spallation (atoms/g/yr.) for a constant production rate model. Multiple results are generated in the online calculator by different publications due to different calculations, these publications include; Lal (1991)/Stone (2000), Desilets et al. (2003, 2006), Dunai (2001), and Lifton and others (2005). For the purpose of this study, Desilets et al. (2003, 2006) exposure ages and external uncertainty are used because it applies the most recent corrections accounting for variability in production rates over time. Results from the online calculator can be found in Table 4.

${ }^{36} \mathrm{Cl}$

Apparent cosmogenic ${ }^{36} \mathrm{Cl}$ surface exposure ages were calculated using ${ }^{36} \mathrm{Cl}$ exposure age calculator, version 2.0 (web1.ittc.ku.edu:8888). The online calculator is based on MATLAB software with 82 input values needed for online calculation. For ${ }^{36} \mathrm{Cl}$, MATLAB calculation is required for certain input values necessary for the online calculator. Effective neutron 
attenuation length $\left(\mathrm{g} / \mathrm{cm}^{3}\right)$ and pressure $(\mathrm{pHa})$ were calculated in MATLAB to generate individual values per sample. The remaining 80 input values were compiled and formatted from field data, AMS and X-ray fluorescence analyses (Table $2 \& 3$ in Appendix). The scaling input selected was DE, standing for Desilets and others $(2003,2006)$, to keep methods consistent with those applied to ${ }^{10} \mathrm{Be}$ samples. Results for major elements and trace elements from bulk rock analysis required for exposure calculation can be found in appendix Table 2. Results from online calculation include; exposure age (kyr), internal uncertainty (kyr), total uncertainty (kyr), erosion rate (mm/kyr), and percent of total production (\%) for $\mathrm{Ca}(\mathrm{sp} .+$ muons), $\mathrm{K}(\mathrm{sp} .+$ muons) and $\mathrm{Cl}$ (Table 5).

\section{Erosion Rate}

Samples were collected at the surface of fault escarpments where rock outcrops were present throughout the Guadalupe Mountains. In order to understand the exposure ages of the samples, an erosion rate was calculated from the same variables used to calculate corresponding exposure ages. In a continuously eroding surface, the top surface of the rock is continually being replaced by a layer just below the surface, this condition is referred to steady-state erosion (Lal, 1991). Samples collected were computed for continuous long-term irradiation because the insitu radionuclides attain the secular equilibrium concentration corresponding to an effective disintegration constant, $\lambda+\mu \varepsilon(\mathrm{Lal}, 1991)$. This was discovered by calculating equations for steady-state erosion laid out by Lal, 1991.

When calculating steady-state erosion the effective irradiation time, $\mathrm{T}_{\text {eff }}$ for the top surface of the rock $(\mathrm{x}=0)$ is given by the following equations: 
$\mathrm{T}_{\text {eff }}=\frac{1}{\lambda+\mu \varepsilon}$

(Equation 1)

$\mathrm{T}_{\text {eff }}=\frac{N(0)}{P(0)}$

(Equation 2)

where $\mathrm{N}(0)$ denotes the nuclide concentration in the top surface of the rock (Lal, 1991). $\mathrm{P}(0)$ represents the production rate of the radionuclide at the target surface (Lal, 1991). In equation 1, the symbol $\lambda$ represents the decay constant for the targeted radionuclide. The absorption constant $(\mu)$ is the mean density $(\rho)$ of target rock divided by the absorption mean free path $(\Lambda)$ for the nuclear interacting particles in the target, $\mu=\rho / \Lambda$ (Lal, 1991). In equation 1 , the symbol $\varepsilon$ denotes the erosion rate of the sample. The model steady-state erosion rate is given by:

$\varepsilon=\frac{1}{\mu}\left[\frac{P(0)}{N(0)}-\lambda\right]$

(Equation 3)

In steady state conditions, the effective surface exposure age of the rock, $\mathrm{T}_{\text {eff }}$, is given by:

$\mathrm{T}_{\mathrm{eff}}=\frac{N(0)}{P(0)}=\frac{1}{\lambda+\mu \varepsilon}$

(Equation 4)

Known data variables were organized into a table. The following variables were calculated, the absorption constant $(\mu)$, the erosion rate $(\varepsilon)$ and the effective exposure age (Teff) (Table 6). 


\section{CHAPTER III: RESULTS}

Surface exposure ages were calculated for samples collected along fault-line escarpments in the study site in order to constrain the timing of events that brought the rocks to the surface. For ${ }^{10} \mathrm{Be}$ samples, the quartz mass, ${ }^{10} \mathrm{Be}$ concentration, local production rate, and apparent exposure ages for the three samples processed are presented in Table 4. For ${ }^{36} \mathrm{Cl}$ samples, the ${ }^{36} \mathrm{Cl}$ concentrations, ${ }^{36} \mathrm{Cl} / \mathrm{Cl}$ ratio, local production rates, and apparent exposure ages for the seven samples processed are presented in Table 5. Calculations from measured concentrations resulted in Pleistocene exposure ages (Figure 7). The surface exposure ages range between 28.1 $\pm 1.9 \mathrm{kyr}(\mathrm{GMAH}-04)$ and $680.0 \pm 396.8 \mathrm{kyr}(\mathrm{WC}-01)$. The youngest exposure ages occur in the southern portion of the study area, and exposure ages increase northward along the transect.

TABLE 4. RESULTS FOR COSMOGENIC ANALYSIS OF SANDSTONE SAMPLES ANALYZED FOR ${ }^{10} \mathrm{BE}$

\begin{tabular}{|c|c|c|c|c|c|}
\hline $\begin{array}{c}\text { Sample } \\
\text { Name }\end{array}$ & $\begin{array}{l}\text { Shielding } \\
\text { Factor }\end{array}$ & $\begin{array}{l}\text { Quartz } \\
\text { Mass } \\
\text { (g) }\end{array}$ & $\begin{array}{c}{ }^{10} \mathrm{Be} \\
\text { Concentration } \\
\left(10^{4} \text { atom } \mathrm{g}^{-1}\right)\end{array}$ & $\begin{array}{c}\text { Production Rate } \\
\text { (Spallation) } \\
\left(\text { atoms } \mathbf{g}^{-1} \mathbf{y r}^{-1}\right)\end{array}$ & $\begin{array}{c}{ }^{10} \mathrm{Be} \\
\text { Exposure } \\
\text { Age (kyr) }\end{array}$ \\
\hline GMLH1302 & 0.98602 & 29.550 & $134.5 \pm 2.4$ & 12.64 & $102.1 \pm 12.7$ \\
\hline GMLH1305 & 0.88235 & 20.420 & $46.7 \pm 1.0$ & 9.69 & $46.0 \pm 5.6$ \\
\hline GMAH-09 & 0.95156 & 21.306 & $43.6 \pm 0.8$ & 14.31 & $29.9 \pm 3.6$ \\
\hline
\end{tabular}

Figure 15. Cross section of the Rim. Locations of samples are labeled with corresponding exposure ages. 


\begin{tabular}{|c|c|c|c|c|c|}
\hline $\begin{array}{c}\text { Sample } \\
\text { Name }\end{array}$ & $\begin{array}{l}\text { Shielding } \\
\text { Factor }\end{array}$ & $\begin{array}{c}{ }^{36} \mathrm{Cl} / \mathrm{Cl} \\
\left(10^{-15}\right)\end{array}$ & $\begin{array}{c}{ }^{36} \mathrm{Cl} \\
\text { Concentration } \\
\left(\mathbf{1 0}^{4} \text { atoms } \mathrm{g}^{-1}\right)\end{array}$ & $\begin{array}{c}\text { Production } \\
\text { Rate } \\
\text { (Spallation) } \\
\left(\text { atoms } \mathbf{g}^{-1} \mathbf{y r}^{-1}\right)\end{array}$ & $\begin{array}{c}{ }^{36} \mathrm{Cl} \\
\text { exposure } \\
\text { age }(\mathbf{k y r})\end{array}$ \\
\hline GMAH-01 & 0.831611 & $295 \pm 11$ & $288.0 \pm 33.5$ & 48.5 & $37 \pm 4.4$ \\
\hline GMAH-03 & 0.919698 & $814 \pm 28$ & $508.8 \pm 26.8$ & 55.0 & $73 \pm 4.6$ \\
\hline GMAH-04 & 0.883872 & $347 \pm 14$ & $174.0 \pm 12.3$ & 57.7 & $28.1 \pm 1.9$ \\
\hline GMAH-06 & 0.941742 & $504 \pm 19$ & $189.7 \pm 12.2$ & 49.5 & $36.2 \pm 2.2$ \\
\hline GMAH-07 & 0.986019 & $1821 \pm 65$ & $1804.0 \pm 207.0$ & 47.8 & $295 \pm 50.2$ \\
\hline GMAH-08 & 0.882351 & $997 \pm 37$ & $675.5 \pm 97.6$ & 43.7 & $121 \pm 19.6$ \\
\hline WC-01 & 0.8572 & $1778 \pm 56$ & $1936.8 \pm 403.8$ & 30.9 & $680 \pm 396.8$ \\
\hline
\end{tabular}


TABLE 6. RESULTS FOR STEADY-STATE CALCULATIONS

\begin{tabular}{|c|c|c|c|c|}
\hline Sample Name & Density ( $\rho)$ & $\begin{array}{l}\text { Attenuation } \\
\text { Length }(\Lambda)\end{array}$ & $\begin{array}{c}\text { Absorption } \\
\text { Coefficient }(\boldsymbol{\mu})\end{array}$ & $\begin{array}{r}\text { Production } \\
\text { Rate } \mathbf{P}(0)\end{array}$ \\
\hline GMAH-04 & 2.56 & 159.2131973 & 0.016079069 & 57.7273 \\
\hline GMAH-06 & 2.56 & 158.9901654 & 0.016101625 & 49.5218 \\
\hline GMAH-01 & 2.56 & 160.5598621 & 0.015944209 & 48.472 \\
\hline GMAH-03 & 2.56 & 160.4713787 & 0.015953001 & 54.9952 \\
\hline GMAH-08 & 2.56 & 159.5954352 & 0.016040559 & 43.6599 \\
\hline GMAH-07 & 2.56 & 160.1577082 & 0.015984245 & 47.8269 \\
\hline WC-01 & 2.56 & 158.3098726 & 0.016170817 & 30.8673 \\
\hline GMAH-09 & 2.65 & 160 & 0.0165625 & 14.31 \\
\hline GMLH1302 & 2.65 & 160 & 0.0165625 & 12.64 \\
\hline GMLH1305 & 2.65 & 160 & 0.0165625 & 9.69 \\
\hline $\begin{array}{c}\text { Nuclide } \\
\text { Concentration } \mathbf{N}(0)\end{array}$ & $\begin{array}{c}\text { Decay } \\
\text { constant }(\lambda)\end{array}$ & $\begin{array}{c}\text { Erosion Rate } \\
(\varepsilon)(\mathrm{cm} / \mathrm{yr})\end{array}$ & $\begin{array}{c}\mathbf{T}_{\text {eff }}= \\
\mathbf{N}(\mathbf{0}) / \mathbf{P}(\mathbf{0})\end{array}$ & $\begin{array}{c}T_{\text {eff }}= \\
(1 /(\lambda+\mu \varepsilon))\end{array}$ \\
\hline $1.74 \mathrm{E}+06$ & $2.3 \mathrm{E}-06$ & $1.92 \mathrm{E}-03$ & $3.01 \mathrm{E}+04$ & $3.01 \mathrm{E}+04$ \\
\hline $1.90 \mathrm{E}+06$ & $2.3 \mathrm{E}-06$ & $1.48 \mathrm{E}-03$ & $3.83 \mathrm{E}+04$ & $3.83 \mathrm{E}+04$ \\
\hline $2.88 \mathrm{E}+06$ & $2.3 \mathrm{E}-06$ & $9.11 \mathrm{E}-04$ & $5.94 \mathrm{E}+04$ & $5.94 \mathrm{E}+04$ \\
\hline $5.09 \mathrm{E}+06$ & $2.3 \mathrm{E}-06$ & $5.33 \mathrm{E}-04$ & $9.25 \mathrm{E}+04$ & $9.25 \mathrm{E}+04$ \\
\hline $6.76 \mathrm{E}+06$ & $2.3 \mathrm{E}-06$ & $2.60 \mathrm{E}-04$ & $1.55 \mathrm{E}+05$ & $1.55 \mathrm{E}+05$ \\
\hline $1.80 \mathrm{E}+07$ & $2.3 \mathrm{E}-06$ & $2.20 \mathrm{E}-05$ & $3.77 \mathrm{E}+05$ & $3.77 \mathrm{E}+05$ \\
\hline $1.94 \mathrm{E}+07$ & $2.3 \mathrm{E}-06$ & 4.37E-05 & $6.27 \mathrm{E}+05$ & $3.33 \mathrm{E}+05$ \\
\hline $4.36 \mathrm{E}+05$ & $4.56 \mathrm{E}-07$ & $1.95 \mathrm{E}-03$ & $3.05 \mathrm{E}+04$ & $3.05 \mathrm{E}+04$ \\
\hline $1.35 \mathrm{E}+06$ & $4.56 \mathrm{E}-07$ & $5.40 \mathrm{E}-04$ & $1.06 \mathrm{E}+05$ & $1.06 \mathrm{E}+05$ \\
\hline $4.67 \mathrm{E}+05$ & $4.56 \mathrm{E}-07$ & $1.22 \mathrm{E}-03$ & $4.82 \mathrm{E}+04$ & $4.82 \mathrm{E}+04$ \\
\hline
\end{tabular}




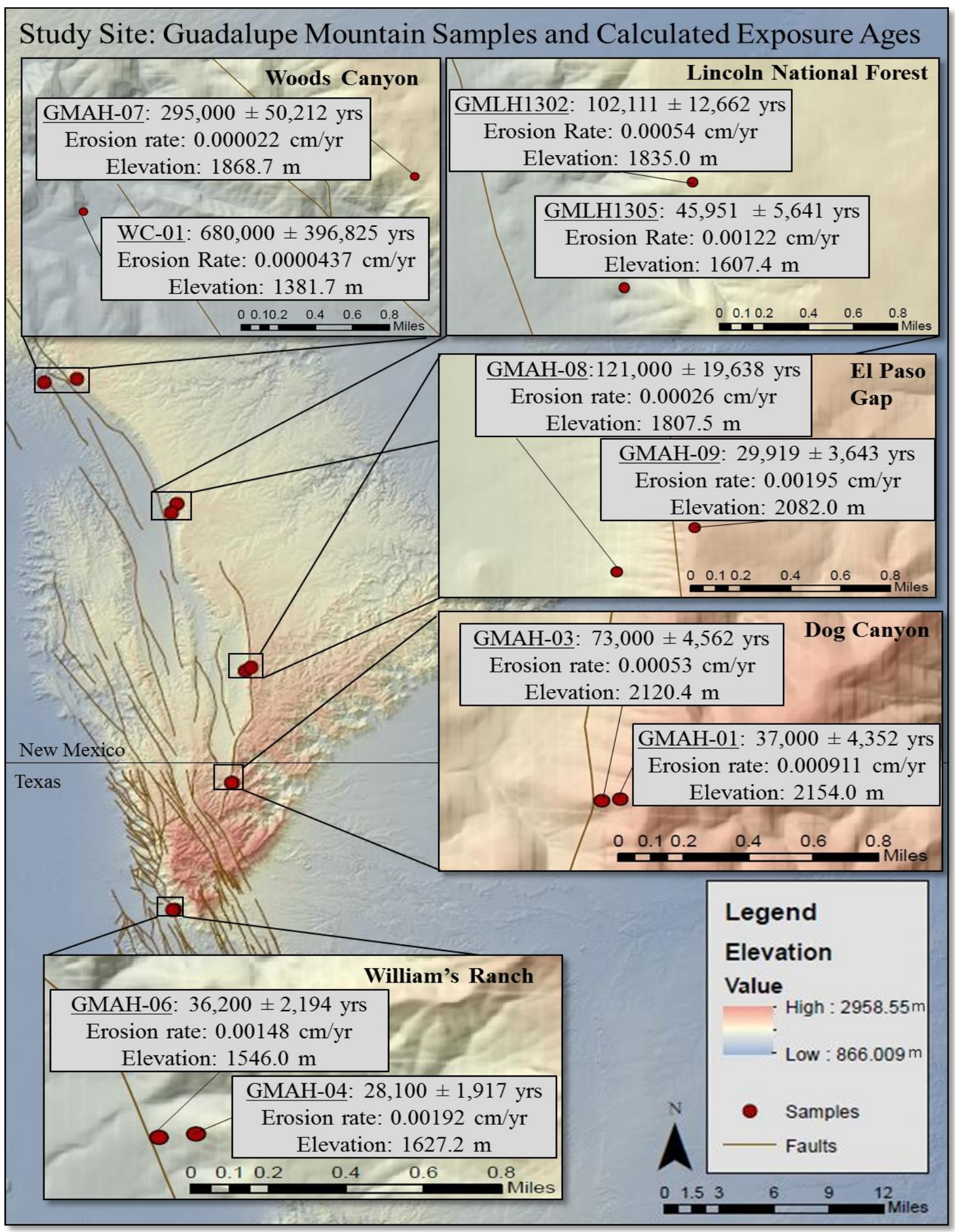

Figure 7. Study site map labeled with results of cosmogenic analysis. 
Maximum calculated erosion rates can be found in Table 6. Samples with longer exposure ages have correspondingly slower erosion rates. Samples with shorter exposure ages have faster erosion rates. In addition to the relationship between apparent exposure ages and

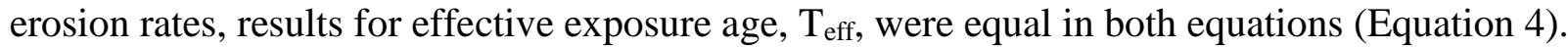
All samples, with the exception of WC-01, obtained secular equilibrium concentrations corresponding to an effective disintegration constant, $\lambda+\mu \varepsilon$. This means that most samples in this study site satisfy the equation:

$\mathrm{T}_{\text {eff }}=\frac{N(0)}{P(0)}=\frac{1}{\lambda+\mu \varepsilon}$ (Equation 4) Therefore, samples are in steady-state erosion, meaning that the surface layer of rock is continually replaced by rocks beneath the surface (Lal, 1991). WC-01 is the only sample that does not follow Equation 4, because the measured concentration of the radionuclide is not equal to the corresponding effective disintegration constant.

Surface exposure age pairs collected on individual escarpments are different, with the exception of the Wood's Canyon location. GMAH-07, the top sample in Wood's Canyon is located $1868.7 \mathrm{~m}$ AMSL and produced an exposure age of $295 \pm 50.2 \mathrm{kyr}$. WC-01, the corresponding bottom sample in Wood's Canyon is located $1381.7 \mathrm{~m}$ AMSL and produced an exposure age of $680 \pm 396.8 \mathrm{kyr}$. While the bottom sample appears much older, we use caution describing these ages as different because uncertainties, particularly in Sample WC-01, are very high (Figure 8). The four remaining sample locations have different exposure ages because uncertainties do not overlap with the corresponding sample (Figure 9). 


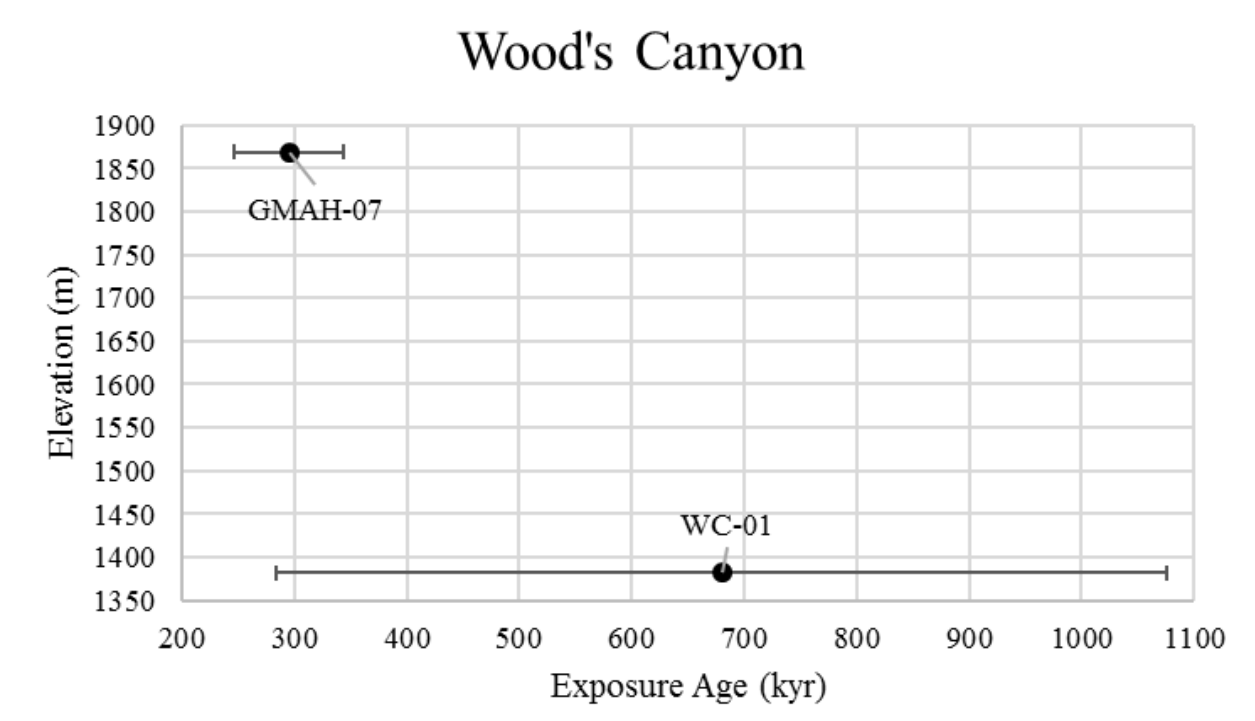

Figure 8. Wood's Canyon exposure ages vs elevation. Calculated exposure ages with respective uncertainties are plotted against elevation for samples collected in Wood's Canyon. The uncertainties overlap between the sample pair, signifying the samples have the same exposure length. 

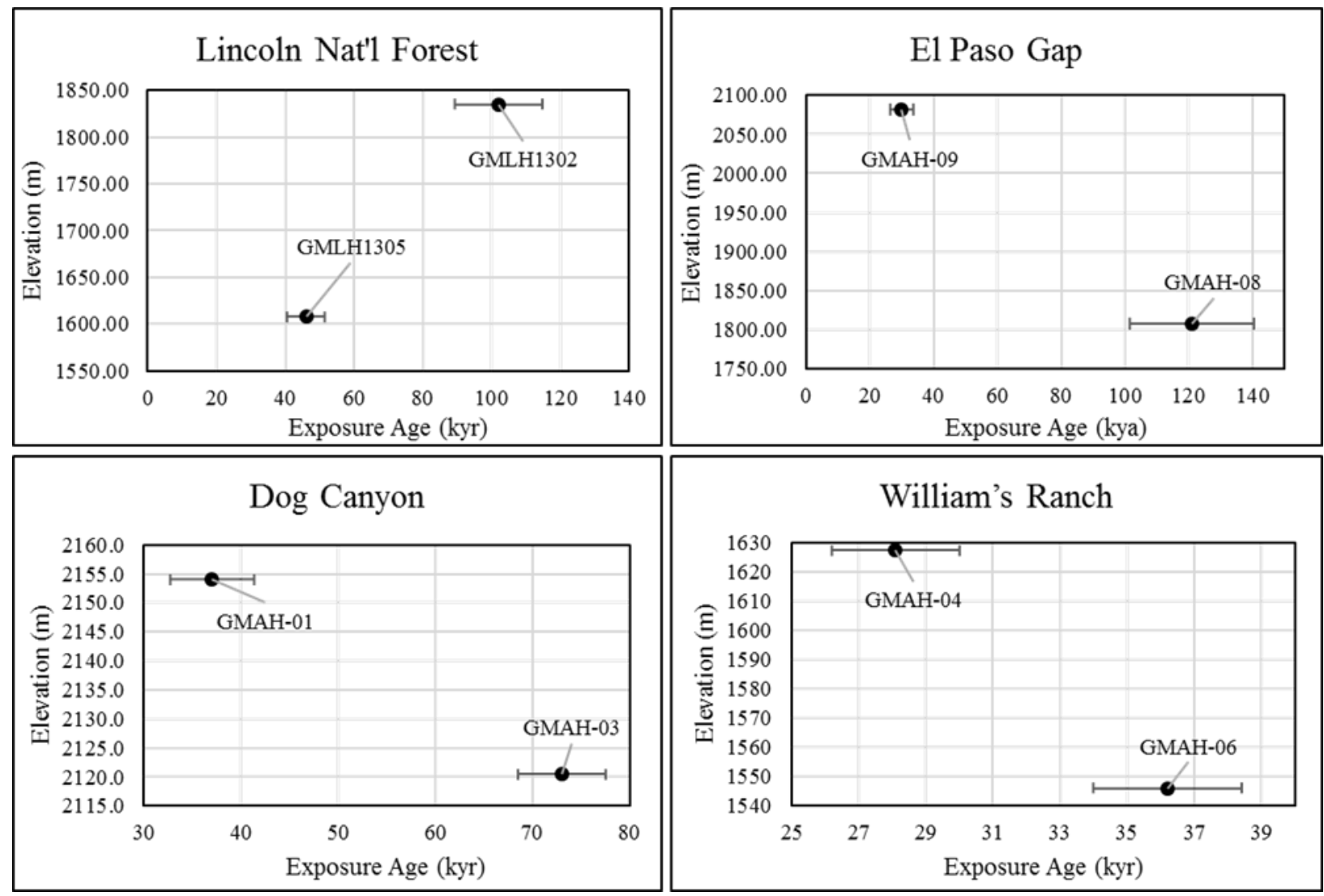

Figure 9. Remaining four locations exposure age vs elevation. Calculated exposure ages with corresponding uncertainties are plotted against elevation at the remaining four locations. Since the sample pairs at all four locations do not overlap in measured uncertainty, the exposure ages are considered different.

Samples collected in the northern portion of the study site increase in exposure age by an order of magnitude compared to samples collected in the south. The top samples in the three southern locations are exposed for shorter amounts of time and are considered to be the same age, because their uncertainties overlap (Figure 10). Top sample exposure ages increase by an order of magnitude between El Paso Gap and Lincoln National Forest locations. GMAH-07 is 
the sample collected at the top of Wood's Canyon and has the oldest exposure age with corresponding low uncertainty.

The samples collected at the bottom of the escarpments do not follow the same increase in exposure ages that top samples follow (Figure 11). Although they increase in exposure age from south to north by an order of magnitude, the increase in exposure age is back and forth between sample locations. The sample collected at the bottom of Lincoln National Forest (GMLH1305) has a shorter exposure age than the samples collected to the north or south by an order of magnitude.

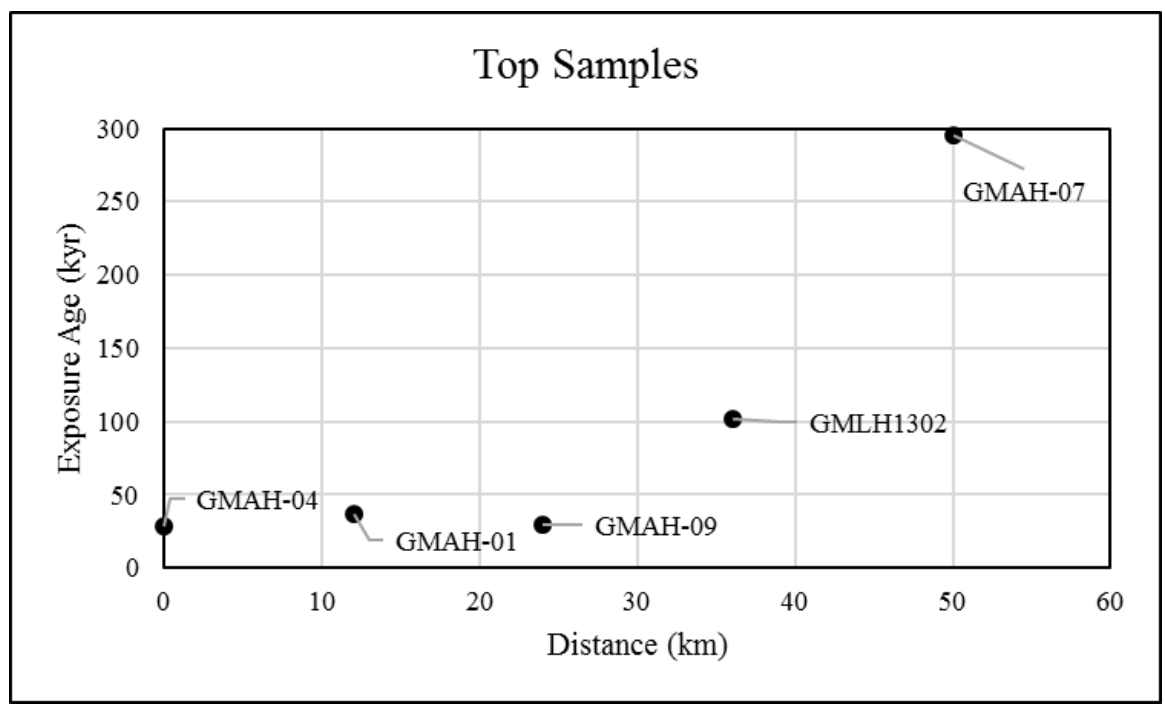

Figure 10. Exposure ages of top samples. Samples collected from the top of escarpments are plotted south to north against exposure age. Samples GMAH-01 and GMAH-09 are considered the same age due to overlapping of exposure uncertainty, therefore samples increase in exposure age from south to north. 


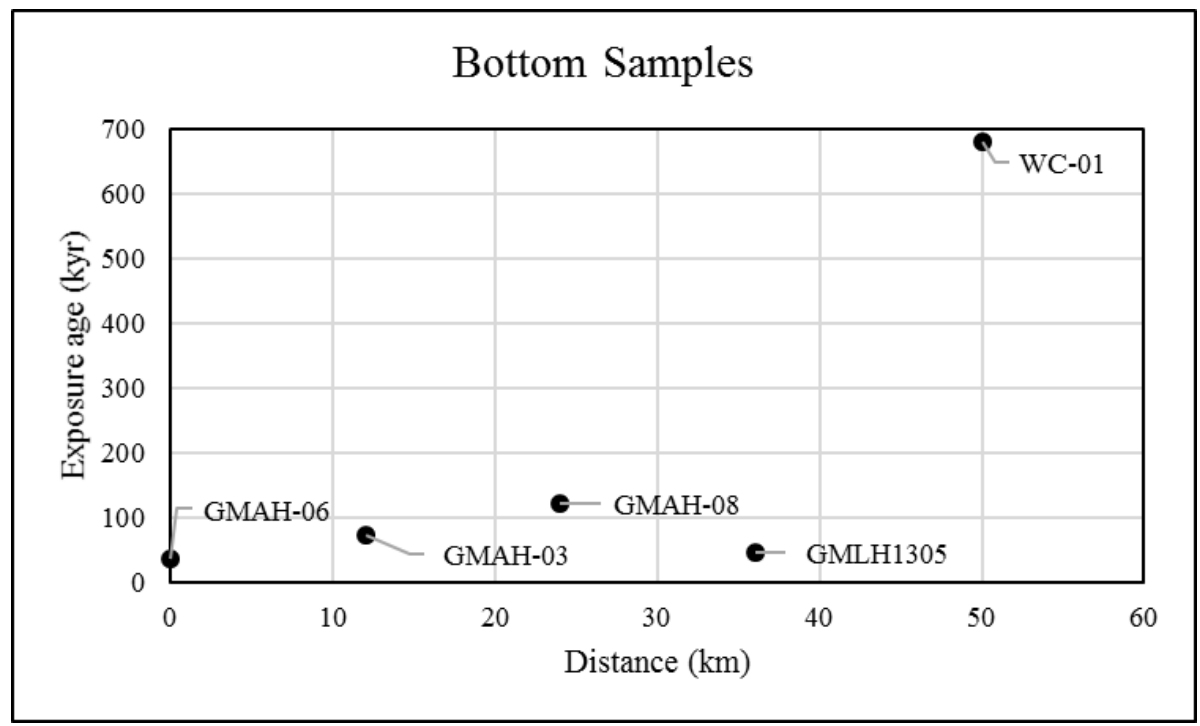

Figure 11. Exposure ages of bottom samples. Samples collected from the bottom of escarpments are plotted from south to north against expoure age. Due to the outlyer GMLH1305, bottom samples do not follow the same trend in exposure ages from north to south.

In addition to the trend seen across the study site, a trend between sample pairs is visible when comparing the top and bottom samples of individual escarpments. Four out of five sample locations have younger exposure ages at the top of the escarpment than at the bottom. The only sample pair that did not follow this trend was collected along the Rim in Lincoln National Forest, where the top sample is older than the bottom sample by an order of magnitude. 


\section{CHAPTER IV: DISCUSSION}

The majority of samples, excluding WC-01, in the study site are experiencing continuous long-term irradiation (Phillips et al., 1986; Lal, 1991). In steady-state conditions, mechanisms forcing erosion such as tectonic regime and climate have remained similar over the timescale represented by the erosion record of interest (Parker and Perg, 2005). All samples analyzed for cosmogenic nuclides are Pleistocene in exposure age ranging up to 600,000 years.

Corresponding erosion rates follow the steady-state trend with the fastest rate of erosion producing younger exposure ages in the southern portion of the range and the slowest rates producing longer exposure ages to the north. The hypothesis that exposure ages would be younger with faster erosion rates in the northern portion of the range, failed. My hypotheses were based on the Rio Grande Rift propagation, however results indicate that the range is influenced more by erosional processes than tectonic processes. The following discussion considers possible erosional degradation of the slopes in the Guadalupe Mountains.

In order to understand the exposure ages and erosion rates visually, cross sections of the sampled escarpments were generated. Multiple cross sections oriented from the top and bottom of individual escarpments illustrate the average shape of the escarpment slopes. Profiles show that the escarpments at all locations have a concave shape. The profiles were drawn to the north and south of where samples were collected in order to understand the overall degradation of the escarpment and average profiles can be found in Figure 12. Resulting profiles for Wood's Canyon and Lincoln National Forest have more variability between profiles, signifying inconsistency in erosional processes. The irregularity could be due to slower erosion rates or location along the Rim, where faults are terminating and beginning in Wood's Canyon. The 
convex shape of Lincoln National Forest could explain the variability in the profile, because the bottom sample is younger in age indicating that the bottom of the slope is degrading faster than the top. The concave shape of the slope of the remaining four escarpments indicates that erosion is the dominant force degrading the escarpment surface (Wallace, 1977; Nash, 1980). Angles were calculated along profiles, and none of the profiles exhibited angles greater than $45^{\circ}$ along any point of the escarpment, indicating that the slope is gravity and debris controlled (Wallace, 1977) (Figures $12 \& 13$ ). Rills notch the crest and channels on the free face transport sediment down the slope and deposit sediment at the base of the scarp. Drainage systems and gullies are pronounced on the surface (Wallace, 1977). Average slopes calculated along the profiles range between $20-38^{\circ}$ indicating that most of the escarpments should be shaped by debris slopes (Wallace, 1977). However, this is not consistent with observations in the field. Slopes had vegetation, such as grass, bushes and trees, growing in thin soil covering in place bedrock at most locations along the escarpment. Debris accumulation was limited to relatively low angled alluvial fans at the mouths of the stream channels and gullies. The profiles also indicate that the escarpments have developed wash slopes, because slopes at the bottom of the escarpments range between $3-15^{\circ}$ (Wallace, 1977). Wash slope angles are consistent with field observations, where debris, such as boulders, were observed at the foot of gullies or the base of escarpments. The faster erosion rates calculated at the top of the escarpments with younger exposure ages imply that the slopes are migrating backwards, which is also supported by the angle of the slope. 

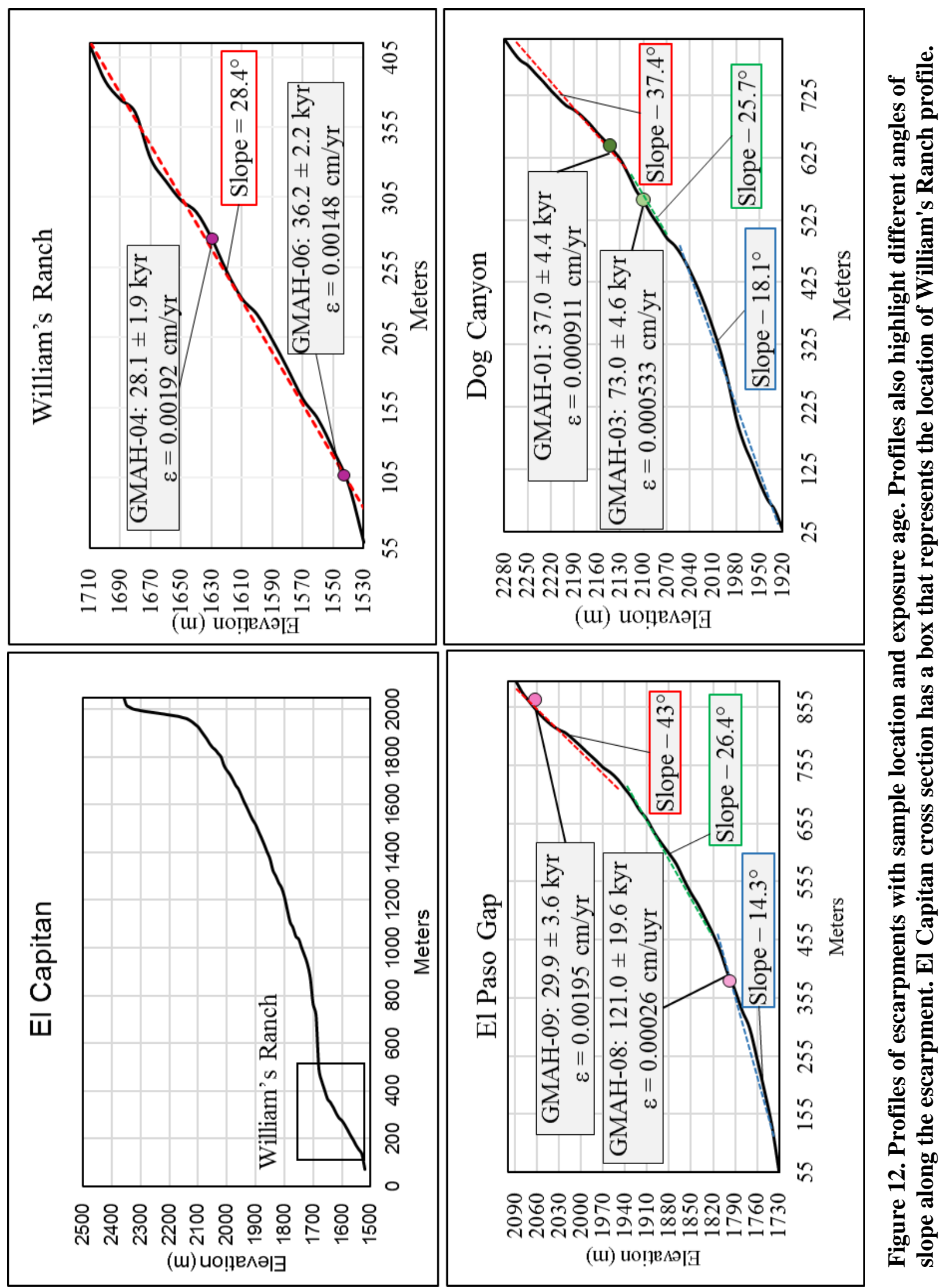

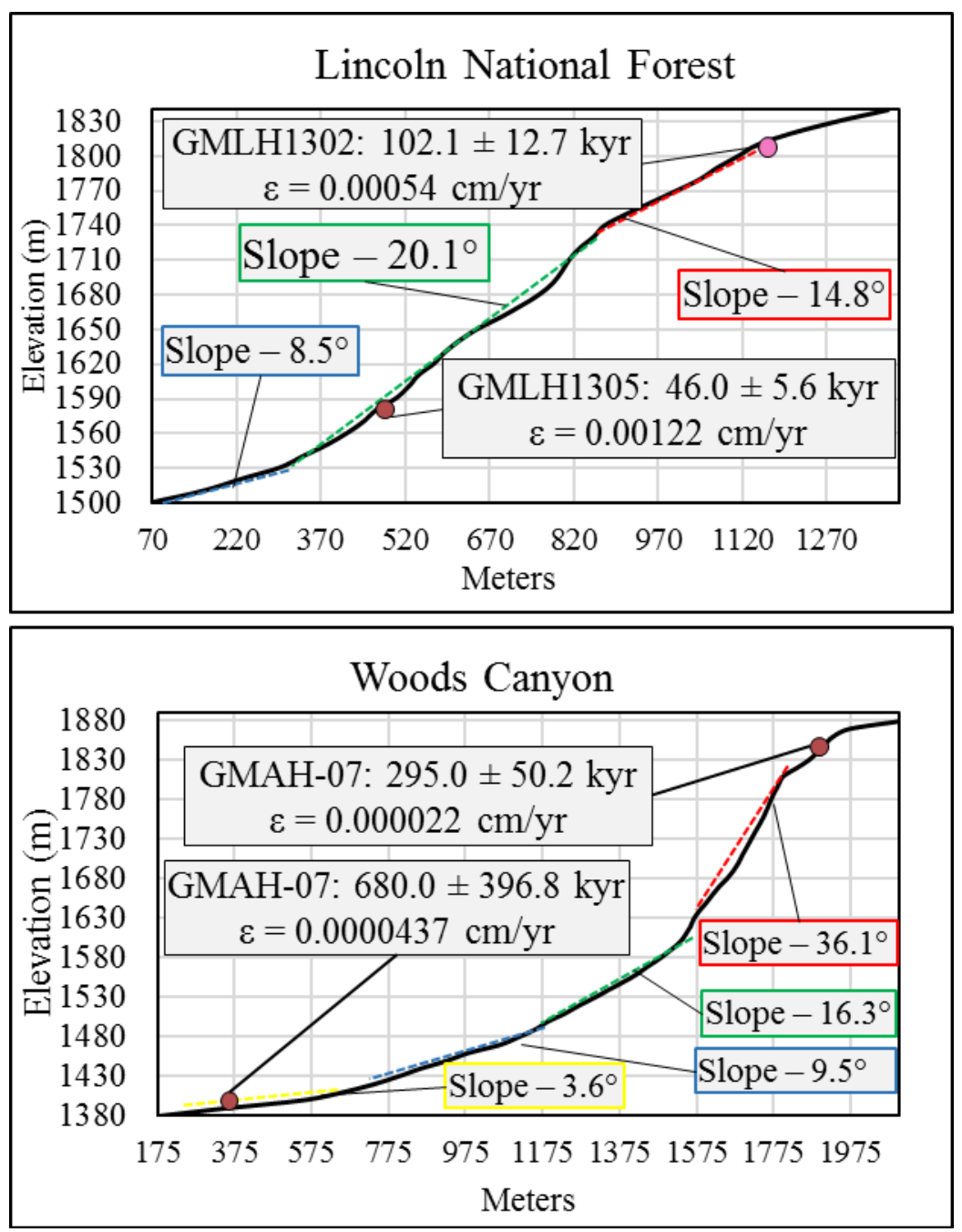

Figure 13. Profiles of remaining escarpments. Continued from figure 12, image shows sample location and exposure age. Profiles highlight different angles of slope along escarpment.

Although the landscape has achieved steady-state conditions, there is variability between exposure age and location. Samples collected at Williams Ranch, Dog Canyon, and El Paso Gap have younger exposure ages than samples collected along escarpments in Lincoln National forest and Wood's Canyon. Trends in exposure ages could be related to the following (in no particular 
order): global climate, local elevation driven climate, distribution of faulted rocks and fault activity, distribution of rock strength, and some combination of any of the above factors.

Global temperatures varied throughout the Pleistocene due to a series of large glacialinterglacial changes with 100,000 year cycles. The Vostok ice core provides insight into the four climate cycles over the last 420,000 years (Petit et al., 1999). According to the ice core data, global temperature repeatedly increased by $10^{\circ} \mathrm{C}$ in a short amount of time $320,000,230,000$, 130,000, and 20,000 years ago (Petit et al., 1999). Spectral analysis emphasizes the dominance of the 100,000 year cycles with a strong imprint of 20,000 - 40,000 year sub-cycles of interglacial and glacial activity (Petit et al., 1999). The last glacial maximum spanned from 50,000 years to 10,000 years ago (Petit et al., 1999). Regional temperature records for the Guadalupe Mountains during the Pleistocene are limited, however, cave formations and different vegetation data provide insight into the last 10,000 years of climate history for the region. Studies of stalagmite growth throughout caves in the region indicate a period that was wetter 4,000 years ago than present day (Polyak and Asmerom, 2001). The vegetation records of ${ }^{14} \mathrm{C}$ in Juniper trees logged a warming and drying period 12,000 years ago, which is consistent with the Vostok ice core data (Petit et al., 1999; Betancourt et al, 2001). When comparing exposure ages of samples in the Guadalupe Mountains with global temperature data, no relationships are apparent. The exposure ages range between $28,000-600,000$ years and do not follow global climate cycles. However, five out of ten samples fall within the period of active glaciation during the last glacial maximum.

The modern climate of Guadalupe Mountains is a semi-arid environment that receives an average annual rainfall of 17.4 inches, with the majority of precipitation occurring in the summer 
months of June through September. In addition, temperature decreases and precipitation increases linearly with elevation throughout the region, in some places it can be $7-10^{\circ} \mathrm{F}$ cooler at higher elevations with stronger winds (NPS, 2017). The local linear trend between elevation, temperature and precipitation could explain the trend between exposure ages and corresponding erosion rates on individual escarpments. Top samples collected on four out of five escarpments had more recent exposure ages with faster erosion rates than the corresponding sample collected at the bottom. Local temperature decreases with increasing elevation, causing increased precipitation and a rise in wind velocity, which in return causes more potential weathering, frost heaving and sediment transport (Wallace, 1977). It is possible that the orographic precipitation due to higher elevation leads to more effective erosional processes, therefore resulting in younger exposure ages associated with higher elevations. The exposure ages graphed against elevation show that there are three clusters of samples, with the exception of the sample collected at the bottom of Wood's Canyon (Figure 14). Samples in the same cluster are within 100 meters of the same elevation. In two of the three clusters, exposure ages and corresponding uncertainties overlap indicating exposure ages are the same between samples on different escarpments.

When comparing samples located at higher elevations and orientation along the Rim, there is a relationship between exposure ages, elevation and location. Samples at higher elevations are in the southern portion of the range where the youngest exposure ages occur. Top sample GMAH-04 collected in the southern most portion of the range at William's Ranch presents the youngest exposure age of $28.1 \pm 1.9 \mathrm{kyr}$ in the study. However, the top sample is not located at the top of the escarpment, it is located near the base of the escarpment at lower elevations (Figure 15). The bottom sample GMAH-06 has been exposed for $36.2 \pm 2.2 \mathrm{kyr}$, 
which is similar to exposure of the top sample. Erosion rates calculated for William's Ranch samples also display some of the fastest erosion rates in the study site. Comparable exposure ages and erosion rates for William's Ranch samples can be found at the top of the next two sampled escarpments in Dog Canyon and El Paso Gap. Apparent exposure ages at the top of Dog Canyon is 37.0 $\pm 4.4 \mathrm{kyr}(\mathrm{GMAH}-01)$ and El Paso Gap is $29.9 \pm 3.6 \mathrm{kyr}$ (GMAH-09). The uncertainties for exposure ages at the top of Dog Canyon and El Paso Gap locations overlap and are considered the same age. The exposure ages of the four samples in the southern portion of the study site fall into a 15,000 year window that is consistent with the last glacial maximum when average global temperatures would have been cooler. Cooler global temperatures in addition to locally cooler temperature conditions could have resulted in more active erosional processes, including freeze-thaw and rockfall process that would have led to faster erosion rates and resulting younger exposure ages on the bedrock surfaces.

Samples collected in the northern portion of the study site are at relatively lower elevations than samples to the south and present exposure ages greater than 100,000 years. Perhaps the lower elevations were sufficient to reduce the impact of different precipitation or temperature conditions associated with the last glacial maximum observed at the southern sites. One exception to this result was sample GMLH1305 in Lincoln National Forest. The GMLH1305 exposure age is $46.0 \pm 5.6 \mathrm{kyr}$, which is also consistent with the last glacial maximum. Field observations identify gravels and cobbles scattering the Lincoln National Forest escarpment with light vegetation where GMLH1305 was collected, signifying recent erosional processes present that could explain the shorter exposure age. Adjacent samples collected at the top of Lincoln National Forest, Wood's Canyon, and at the bottom of El Paso 
Gap escarpments range in exposure age between 102.1 $\pm 12.6 \mathrm{kyr}$ (GMLH1302) to $680 \pm 396.8$ kyr (WC-01).

The longest exposure age is located at the bottom of Wood's Canyon escarpment and has the lowest elevation in the study site. In addition to longest exposure age, WC-01 has the slowest erosion rate at $0.0000437 \mathrm{~cm} / \mathrm{yr}$. WC-01 also has the largest exposure uncertainty, which could be related to the measured concentration ratio and corresponding disintegration constant not equaling and the difference between equations being equal to WC-01 age uncertainty (Table 6) (Lal, 1991). The exposure age of WC-01 when calculated from the ratio of nuclide concentration and respective production rate is almost double the exposure age for the corresponding disintegration constant. The disintegration constant calculates the exposure age based on erosion rate, decay constant, and absorption coefficient (Lal, 1991). The concentration of nuclide in WC-01 is almost twice the amount for steady-state conditions. One possible explanation for excessive nuclide concentration is inherited nuclides from previous exposure (Akcar et al., 2009). Due to the location of Wood's Canyon sample at the bottom of the escarpment, it is possible that the sample was once buried from a mass movement of sediment depositing over the surface thick enough to shield cosmic ray interactions, before eventually resurfacing. 

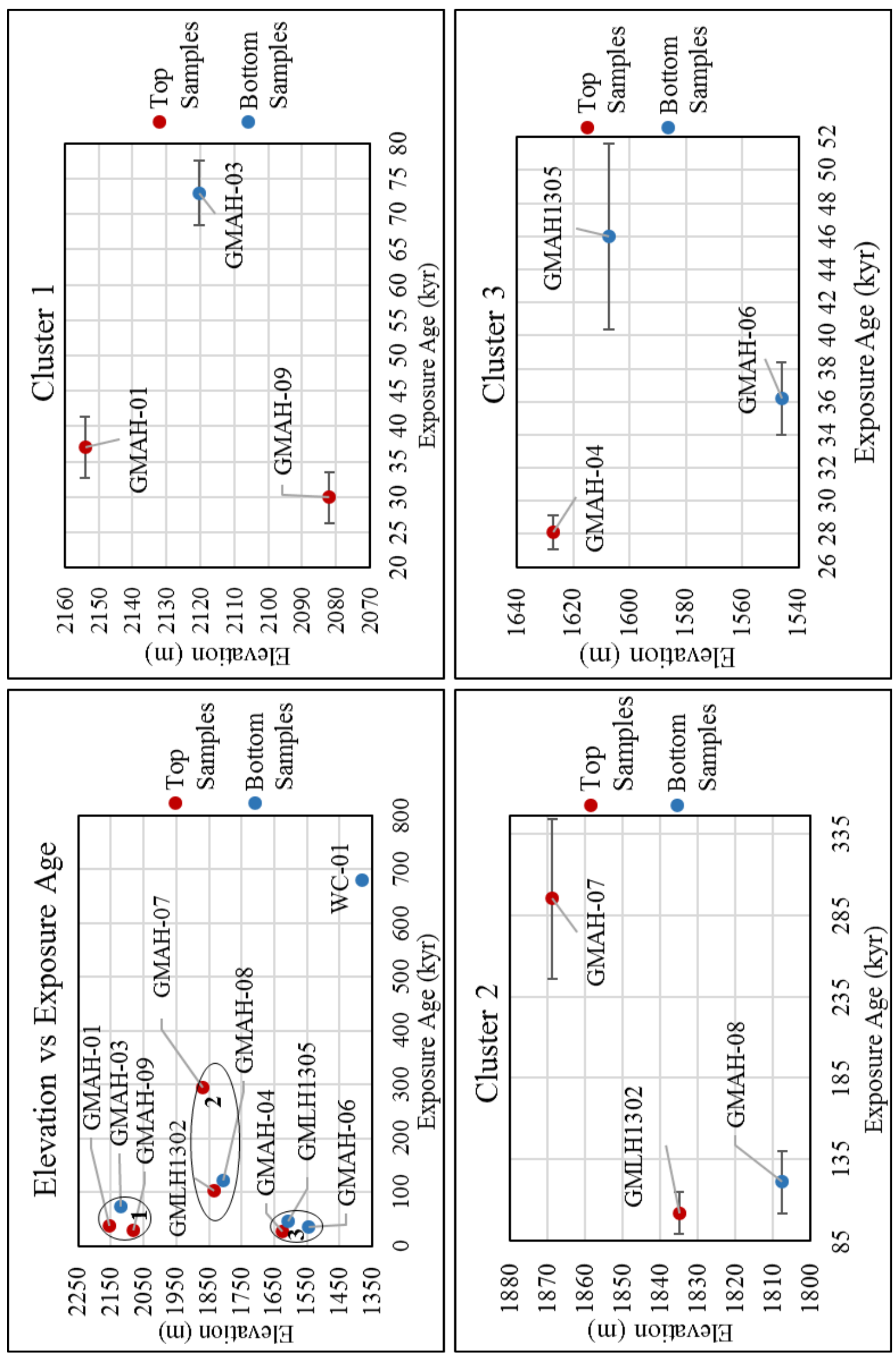

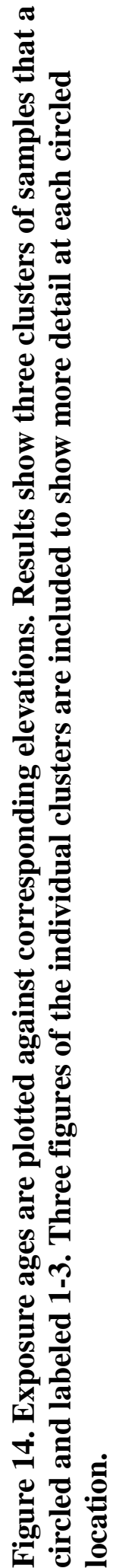




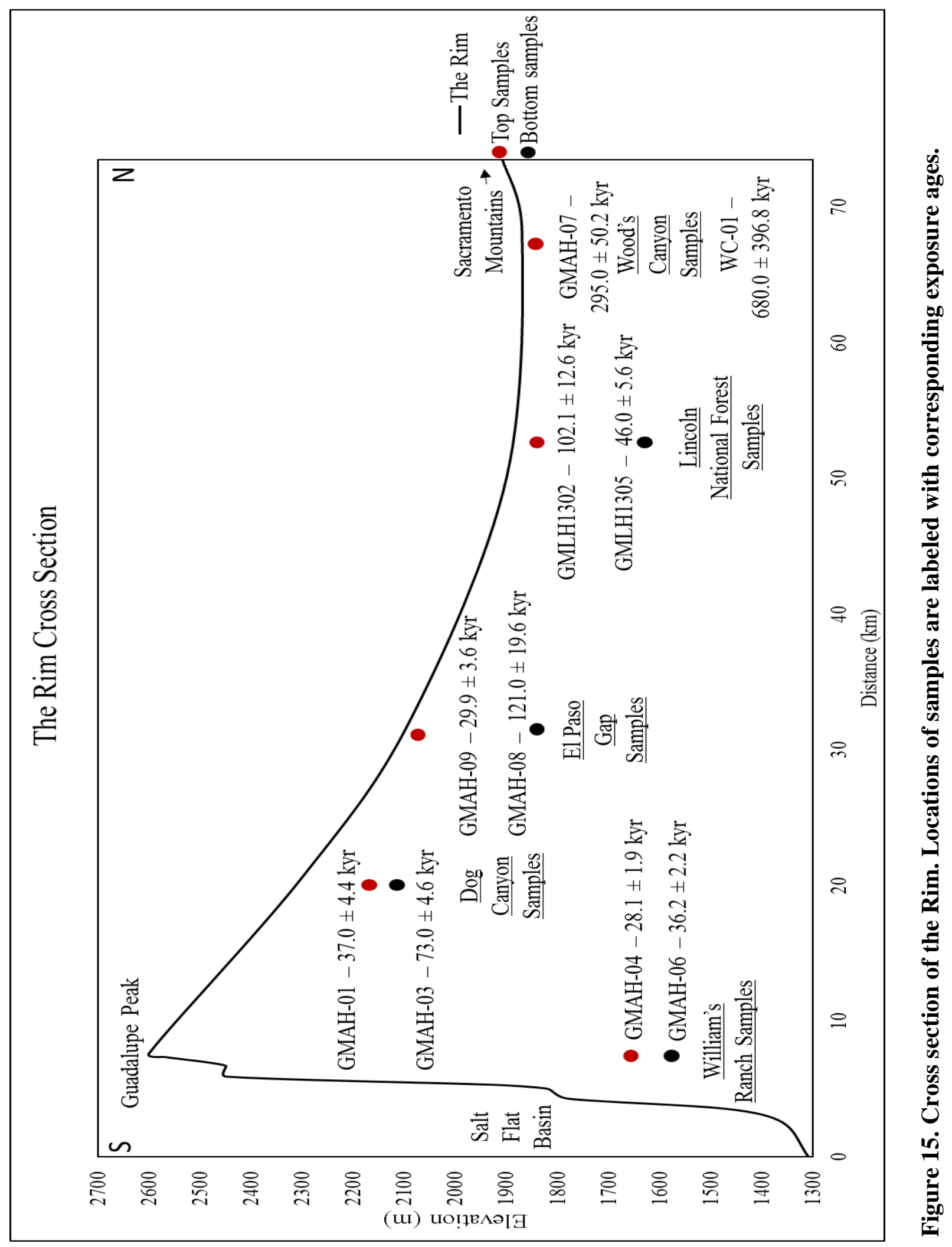


When comparing sample exposure ages and elevations to location, there is a connection between sample location and exposure. A possibility for the connection is the distribution of variation in rock strength between rocks in the fore reef and back reef. The material that the faulted rocks are made of directly affects the way the faults will erode (Wallace, 1977; Nash, 1980). The Guadalupe Mountains are composed of Permian rocks that make up the Capitan Reef complex (Hill, 2000). The fore reef portion of the Capitan Reef complex consists of massive beds of limestone that are highly resistant and frame the scenic landscape. The back reef portion of the complex consists of limestone interbedded with siliciclastic materials typical of back reef formation, including sandstones, shales and evaporates (Hill, 2000). Figure 16 provides the geologic map for the study site with corresponding geologic formation descriptions in Figures 17 and 18. Profiles of the sampled escarpments with geologic formations labeled can be found in Figures $19 \& 20$. 




Figure 16. Geologic map of the study site. 


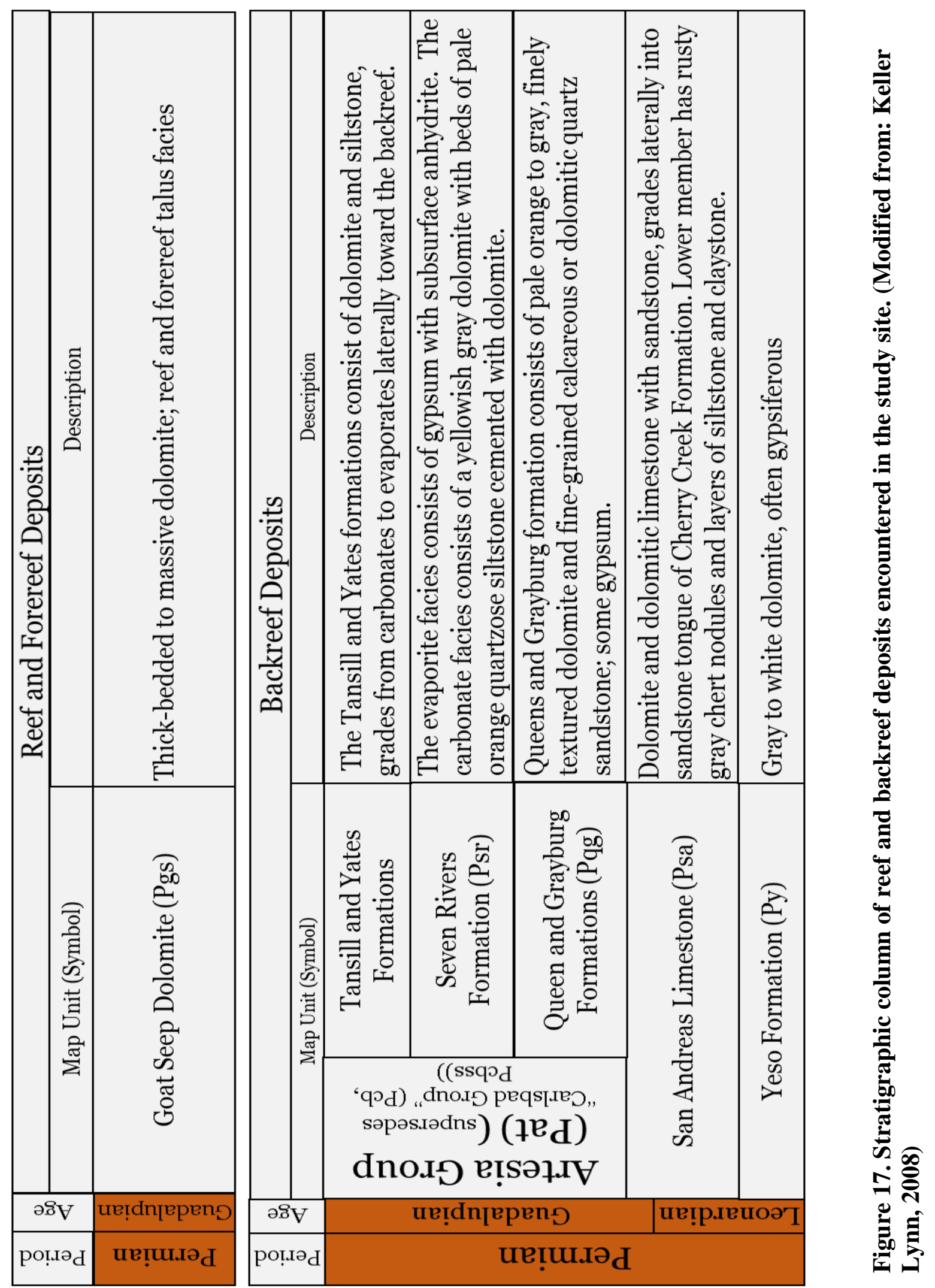




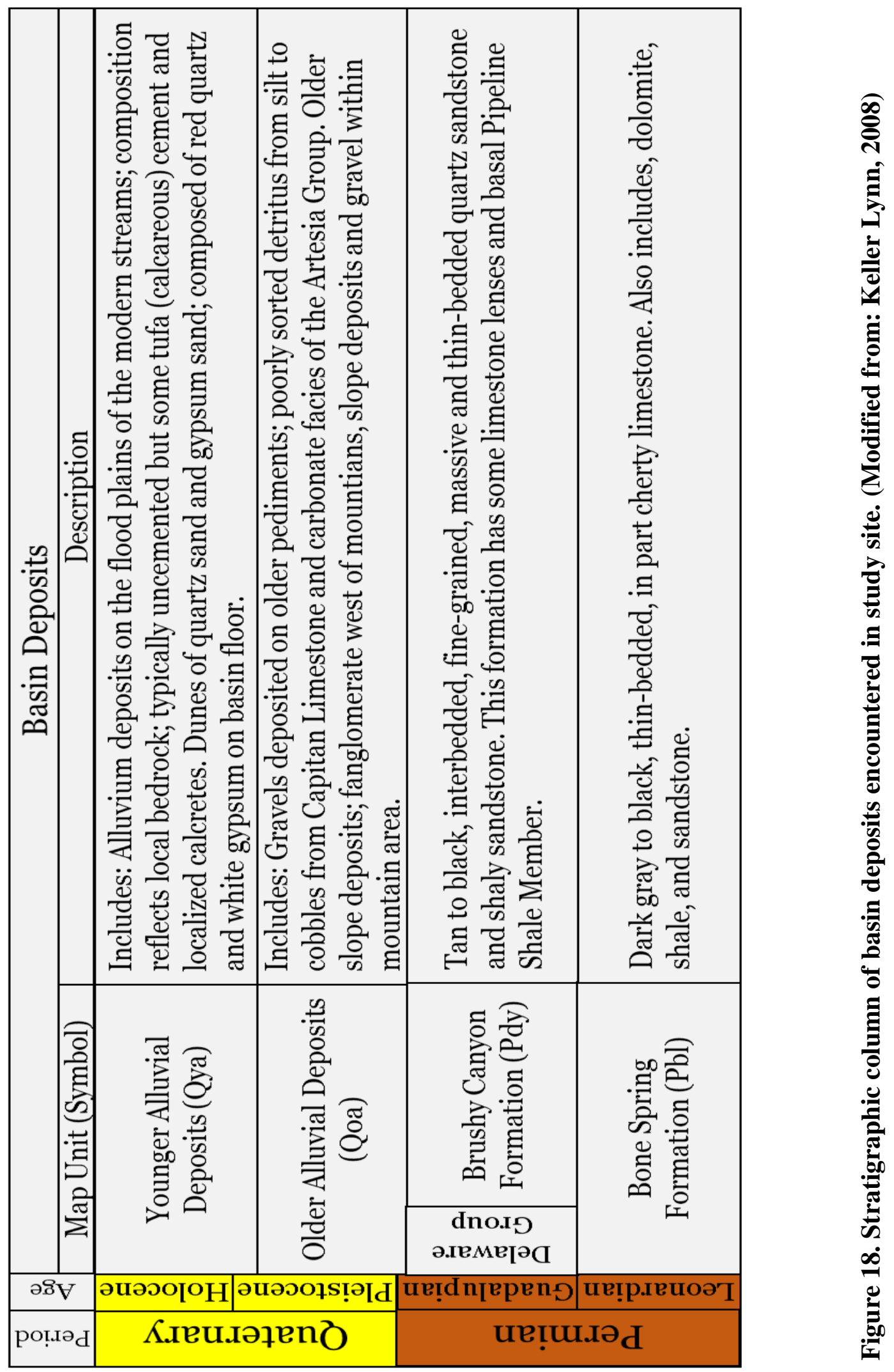




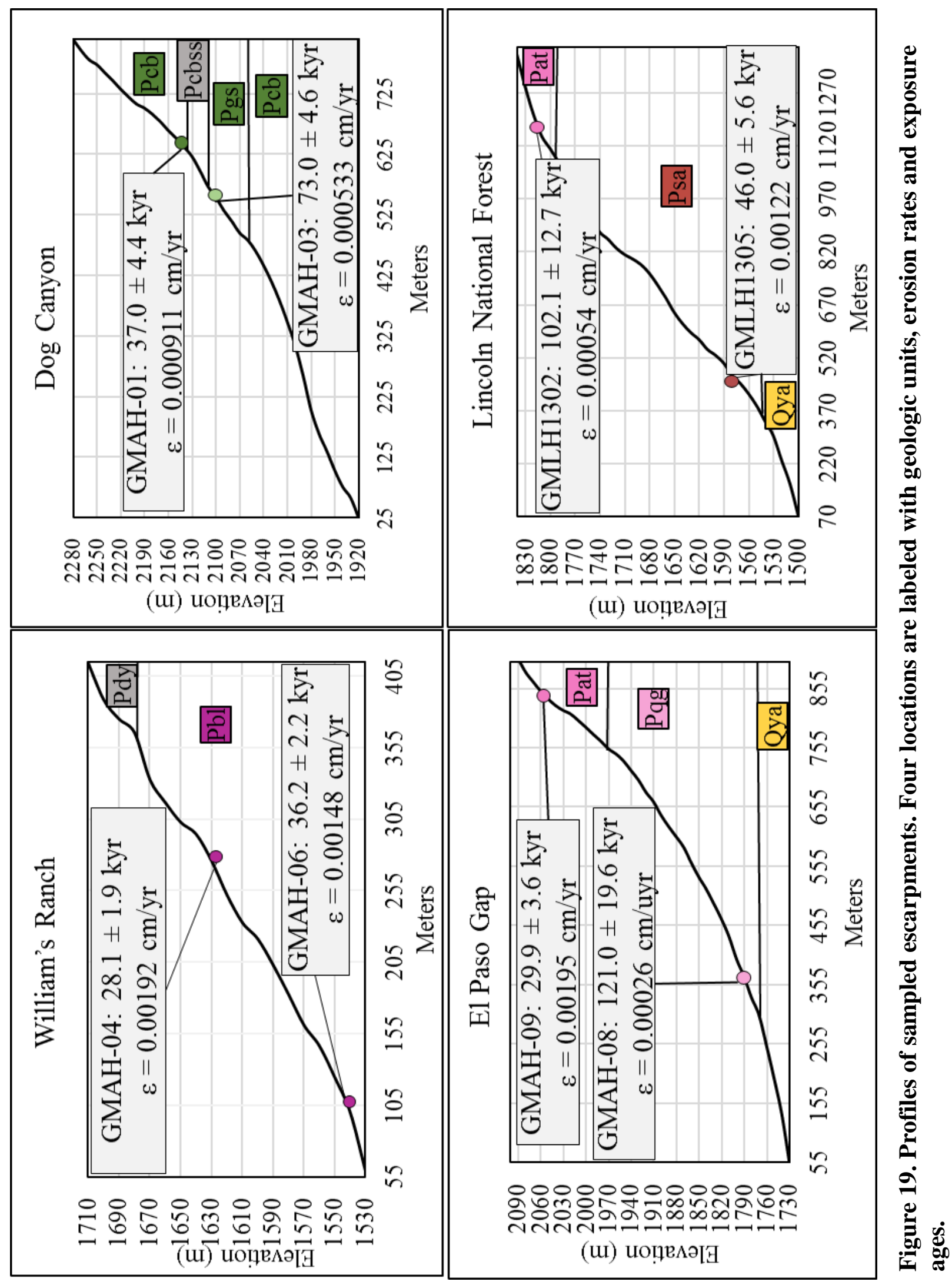




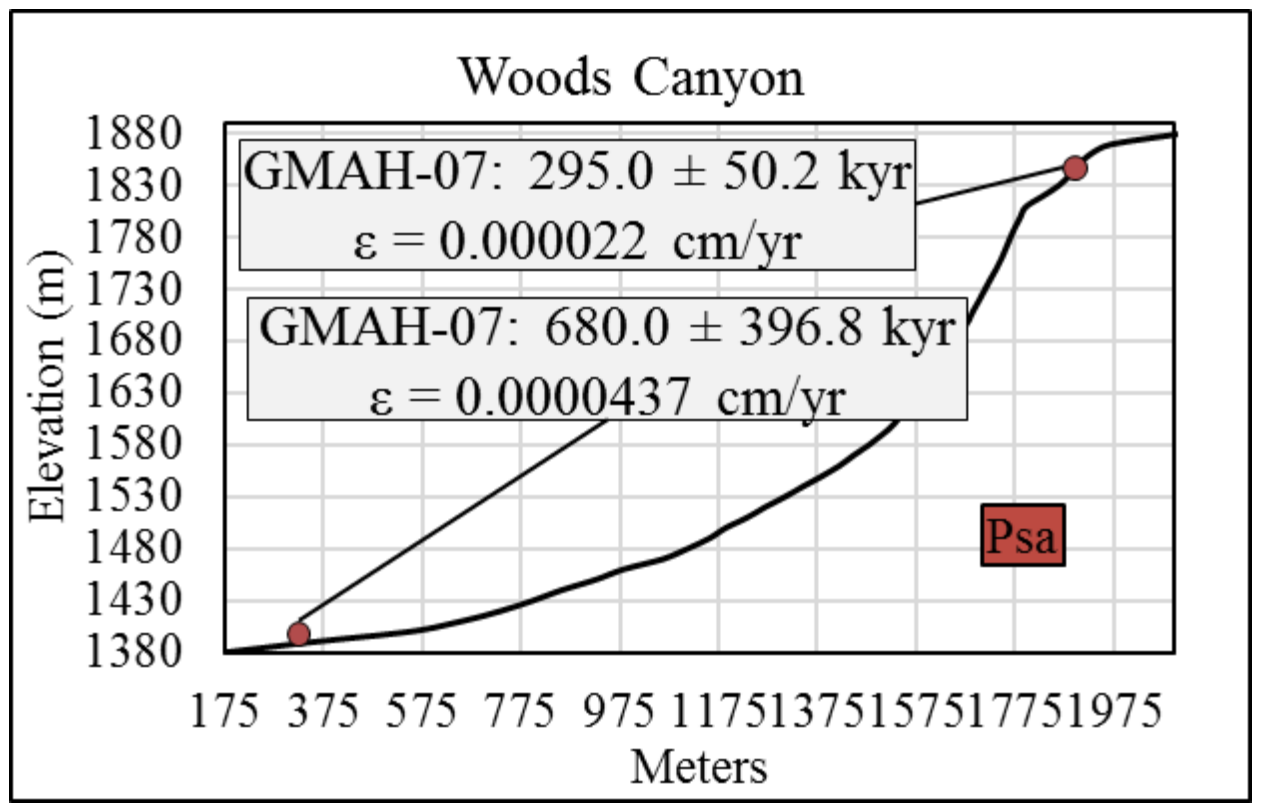

Figure 20- Profile of Wood's Canyon escarpment. Geologic units, erosion rates and exposure ages are labeled

Limestone strength is dictated by the amount of micrite present and sandstone hardness is dictated by the quartz content, grain contact and packing density (Sabatakakis et al., 2008).

Rebound values recorded from an N-type Schmidt rock hammer in the fore reef formations were above 65, indicating resistant rocks (Schoenmann, 2017). Rebound values collected from the Carlsbad limestone (Pcb) and sandstone (Pcbss) in the back reef formations were statistically the same as the fore reef formations (Schoenmann, 2017). The measured rebound values indicate that rock strength is comparatively the same for rocks sampled in fore reef and back reef formations outcropping in two canyons shaping the southern Guadalupe Mountains, but these values only represent a small portion of sample rocks for this study. The interbedded 
environment of the back reef composed of limestone, siliciclastic, and evaporate beds provide more erosive material than the fore reef that is lined with thick beds of limestone. In addition, Wood's Canyon and Lincoln National Forest escarpments are located in the back reef and exhibit more variability between cross section profiles that could be due to rock strength variances in back reef formations. Unfortunately, rock strength data available only covers fore reef and back reef formations outcropping in two canyons present in the southern portion of the range. Rock strength data for the southern portion of the range suggests that fore reef and back reef formations are similar and generated profiles of escarpments in the southern portion of the range have the same overall shape and backward migration.

The fault distribution in the area provides another explanation for the relationship between exposure ages and location in the Guadalupe Mountains. Mapped faults are present throughout the region; however, there are more faults in the southern portion of the range where the youngest exposure ages and fastest erosion rates are calculated. The fault zone narrows to the north, where the rocks have been exposed for a longer period of time due to slower erosion rates. The degradation of scarps depends on the rate at which surface processes loosen material from the slope face (Nash, 1980). Footwall displacement and relief enhances orographic precipitation, thereby enhancing escarpment erosion rates (Densmore et al., 2004). Erosion rates depend strongly on surface height and vary with changes in rainfall, thus an increase in erosion rate may simply reflect a change in climate alone and a more rapid lowering of the surface (England and Molar, 1990). The presence of more faults implies more fractures, broken rocks and areas of weakness, which provide more ways for water to seep into rock and drive the degradation of the escarpment (Wallace, 1977; Nash, 1980). Fractures allow the break down of 
rocks by processes including frost heaving, gully formation and mass wasting events (Wallace, 1977; Nash, 1980; Densmore et al., 1998). The escarpments in the southern portion of the range have more relief and are elevated higher than the escarpments to the north. Corresponding exposure ages and erosion rates are younger and eroding faster in the southern portion of the range. The trend between faulting and exposure ages does not support my hypothesis that exposure ages would be youngest in the northern portion of the range and increase in exposure to the south due to the propagation of the Rio Grande Rift. Instead it appears that more rapid erosion could occur in the south related to more fractured rock, easier sediment mobility, cooler temperatures and higher precipitation conditions.

Due to the limited number of samples collected, it is difficult to fully detail variations in the geomorphic processes occurring in the Guadalupe Mountains. The examination of exposure ages and erosion rates of sample bedrock surfaces at five different locations throughout the Guadalupe Mountains resulted in more questions than answers about the landscape evolution. For example, why are exposure ages younger to the south? Future work with cosmogenic nuclides is needed on escarpment surfaces and adjacent catchment basins throughout the range to deliver a better understanding of the current processes shaping the terrain. Future cosmogenic sampling along fault escarpments should include more samples along the slope. Adjacent catchment basins should also be analyzed by collecting sediments to improve the overall understanding of the degradation of the escarpments in relation to nearby sedimentary basins. Consistent exposure intervals between sample locations on single escarpments coupled with catchment-wide erosion rates and corresponding rock strength values could generate important data needed to produce an erosional model of the scarp formation. The location of future 
cosmogenic sampling should take place in the southern portion of the range on both the eastern and western escarpments, to see if there is any spatial or temporal correlation between surface exposures. Furthermore, one possible explanation for the trend between erosion, exposure, and location not discussed previously is isostatic rebound and its effect on the current landscape evolution. Future work in cosmogenic analysis of fault escarpments and adjacent sedimentary basins throughout the Guadalupe Mountains could provide valuable insight into different conditions necessary to model the formation of the slope. 


\section{CHAPTER V: CONCLUSION}

The Guadalupe Mountains prove to be an interesting structure to examine due to the extensional features produced by regional tectonics. Exposure ages of bedrock samples collected on the Rim are Pleistocene in age. A trend between shorter exposure ages and faster erosion rates are located in the southern portion of the range and increase in exposure to the north. Coincidently, the southern portion of the range has more mapped faults and higher escarpment relief, causing orographic precipitation that result in increased erosion. Additionally, results conclude that steady-state conditions have been reached in the Guadalupe Mountains, meaning that the evidence of tectonic exhumation are being eroded away at the same rate. The semi-arid nature of the region also indicates that erosion is occurring at a slower rate overall because sufficient water required to erode bedrock is only available during large precipitation events.

The number of samples collected in this study is not adequate to answer all the questions about the geomorphic evolution of the Guadalupe Mountains. This study only scratched the surface to begin quantifying exposure and erosion rates required to interpret the geomorphic evolution of this range. More work on constraining the time it took to create the present landscape is still needed. The exposure ages only provide a brief insight into the development of five separate segments of a distinct escarpment. 


\section{REFERENCES}

Akcar, N., Ivy-Ochs, S., Alfimov, V., Yilmaz, I.O., Schachner, A., Altiner, D., Yavuz, V., and Schlutchter, C., 2009, First results on determination of cosmogenic ${ }^{36} \mathrm{Cl}$ in limestone from the Yenicekale Complex in the Hittite capital of Hattusha (Turkey): Quaternary Geochronology, v. 4, i. 6, p. 533-540, doi:10.1016/j.quageo.2009.09.002

Balco, G., Stone, O.J., Dunai, J.T., 2008, A complete and easily accessible means of calculating surface exposure ages of erosion rates from ${ }^{10} \mathrm{Be}$ and ${ }^{26} \mathrm{Al}$ measurements: UW Quaternary Geochronology, v. 3, i. 3, p. 174-195 doi: 10.1016/j.quageo.2007.12.001

Barrow, R., and Keller, G.R., 1994, An integrated geophysical study of the Estancia Basin, central New Mexico, in Keller, G.R., and Cather, S.M., eds, Basins of Rio Grande Rift: Structure, Stratigraphy and Tectonic Setting, Geological Society of America, Special Paper 291, p. 171-186 doi: 10.1130/SPE291

Betancourt, J.L., Rylander, K.A., Penalba, C., and McVickar, J.L., 2001, Late Quaternary vegetation history of Rough Canyon, south-central New Mexico, USA: Palaeogeography, Palaeoclimatology, Palaeoecology, v. 165, p. 71-95

Buck, W.R., 1991, Modes of continental lithospheric extension: Journal of Geophysical Research, v. 96, n. B12, p. 20,161-20,178 doi:10.1029/91JB01485

Bryd, J.O., Smith, R.B., and Geissman, J.W., 1994, The Teton fault, Wyoming: topographic signature neotectonics, and mechanisms of deformation: Journal of Geophysical Research, v. 99, n. B10, p. 20,095-20,122, doi: 10.1029/94JB00281

Densmore, A.L., Dawers, N.H., Gupta, S., Guidon, R., and Goldin, T., 2004, Footwall topographic development during continental extension: Journal of Geophysical Research, v. 109, F03001, p. 1-16 doi: 10.1029/2003JF000115

Densmore, A.L., Ellis, M.A., and Anderson, R.S., 1998, Landsliding and the evolution of normal fault bounded mountains: Journal of Geophysical Research, v. 103, no. B7, p. 15,20315,219 doi:10.1028/98JB00510

England, P., and Molnar, P., 1990, Surface uplift, uplift of rocks, and exhumation of rocks: Geology, v. 18, no. 12, p. 1173-1177 doi: 10.1130/0091-7613

Federici, P.R., Granger, D.E., Ribolini, A., Spagnolo, M., Pappalardo, M., and Cyr, A.J., 2011, Last glacial maximum and the gschnitz stadial in the maritime alps according to ${ }^{10} \mathrm{Be}$ cosmogenic dating: Boreas, v. 41, i. 2, p. 1-16 doi:10.1111/j.1502-3885.2011.00233.x 
Gao, W., Grand, S.P., Baldridge, W.S., Wilson, B., West, M., Ni, J.F., and Aster, R., 2004, Upper mantle convection beneath central Rio Grande rift imaged by $\mathrm{P}$ and $\mathrm{S}$ wave tomography: Journal of Geophysical Research, v. 109, B03305, doi:10.1029/2003JB002743.

Granger, D.E., Kirchner, J.W., and Finkel, R., 1996, Spatially averaged long-term erosion rates measured from in situ- produced cosmogenic nuclides in alluvial sediment: The Journal of Geology, v. 104 , no. 3 , p. $249-257$

Gosse, J.C., and Phillips, F.M., 2001, Terrestrial in situ cosmogenic nuclides: theory and application: Quaternary Science Reviews, v. 20, i. 14, p. 1475-1560 doi:10.1015/S02773791

Hanks, T.C., Bucknam, R.C., Lajoie, K.R., and Wallace, R.E., 1984, Modification of wave-cut and faulting controlled landforms: Journal of Geophysical Research, v. 89, i. B7, p. 5771-5790 doi: 10.1029/JB089iB07p05771

Hill, C.A., 2000, Overview of the geologic history of cave development in the Guadalupe Mountains, New Mexico: Journal of Cave and Karst Studies, v. 62, i. 2, p. 60-71

Hoffman, L.L., 2014, Spatial variability of erosion patterns along the eastern margin of the Rio Grande Rift [M.S. thesis]: Normal, Illinois State University, p. 71

Ivy-Ochs, S., and Kober, F., 2008, Surface exposure dating with cosmogenic nuclides: Quaternary Science Journal, v. 57, i. 1, p. 179-209

Keller, G.R., and Baldridge, W.S., 1999, The Rio Grande rift: A geologic and Geophysical overview, Rocky Mountain Geology, v. 34, no. 1, p. 121-130 doi: 10.2113/34.1.121

Keller Lynn, K., 2008, Guadalupe Mountains National Park Geologic resource evaluation report: Natural Resource Report NPS/NRPC/GRD/NRR, National Park Service, Denver, Colorado, p. 1-46

King, P.B., 1948, Geology of the southern Guadalupe Mountains, Texas: U.S. Geological Survey Professional Paper, v. 215, p. 1-183.

Lal, D., 1991, Cosmic ray labeling of erosion surfaces: in situ nuclide production rates and erosion models: Earth and Planetary Science letters, v. 104, p. 424-439.

Leeder, M.R., Jackson, J.A., 1993, Drainage systems and the development of normal faults, an example from Pleasant Valley, Nevada: Journal of Structural Geology, v. 16, i. 8, p. 1041-1059 doi: 10.1016/0191-814(94)90051-5 
Leeder, M.R., Jackson, J.A., 1993, The interaction between normal faulting and drainage in active extensional basins, with examples from the western United States and central Greece: Basin Research, v. 5, i. 2, p. 79-102 doi: 10.1111/j.1365- 2117. 1993.tb0059x

Marrero, S.M., Phillips, F.M., Borchers, B., Lifton, N., Aumer, R., and Balco, G., 2015, Cosmogenic Nuclide Systematics and the CRONUScalc Program: Preprint submitted to Quaternary Geochronology, p. 1-92

Moucha, R., 2008, Mantle convection and the recent evolution of the Colorado Plateau and the Rio Grande Rift Valley: Geological Society of America, Geology, v. 36, No. 6, p. 439442 doi: 10.1130/G24577A.1

Nash, D.B., 1980, Morphological dataing of degraded normal fault scarps: Journal of Geology, v. 88 , i. 3, p. 353-360 doi: $10.1086 / 628513$

Nishiizumi, k., Kohl, C.P., Arnold, J.R., Dorn, R., Klein, J., Fink, D., Middleton, R., and Lal, D., 1993, Role of in situ cosmogenic nuclides ${ }^{10} \mathrm{Be}$ and ${ }^{26} \mathrm{Al}$ in the study of diverse geomorphic processes: Earth Surface Processes and Landforms, v. 18, p. 407-425 doi:10.1002/esp.3290180504

National Park Sevice, 2017, Guadalupe Mountains National Park Weather: (accessed 4/21/2017).

Palumbo, L., Hetzal, R., Tao, M., Li, X., and Guo, J., 2009, Deciphering the rate of mountain growth during topographic presteady state: An example from the NE margin of the Tibetan Plateau: AGU Journal; Tectonics, v. 28, i. 4, p. 1-18 doi:10.1029/2009TC002455

Parker, G., and Perg, L.A., 2005, Probabilistic formulation of conservation of cosmogenic nuclides: effect of surface elevation fluctuations on approach to steady state: Earth Surface Processes and Landforms, v. 30, i. 9, p. 1127-1144 doi: 10.1002/esp.1266

Petit, J.R., Jouzel, J., Raynaud, D., Barkov, N.I., Barnola, J.M., Basille, I., Benders, M., Chappellaz, J., Davis, M., Delaygue, G., Delmotte, M., Kotlykov, M.V., Legrand, M., Lipenkov, V.Y., Lorius, C., Pepin, C., Ritz, C., Saltzman, E., and Stievenard, M., 1999, Climate and atmospheric history of the past 420,000 years from the Vostok ice core, Antartica: Nature, v. 399, p. 429-436

Phillips, F.M., Ayarbe, J.P., Bruce, J., Harrison, J., Elmore, D., 2003, Dating rupture events on alluvial fault scarps using cosmogenic nuclides and scarp morphology: Earth and Planetary Science Letters, v. 215, i. 1, p. 203-218 doi:10.1016/S0012-821X(03)00419-9

Phillips, F.M., Leavy, B.D., Jannik, N.O., Elmore, D., and Kubik, P.W., 1986, The accumulation of cosmogenic chlorine 36 in rocks, a method for surface exposure dating: American Association for the advancement of Science, v. 231, no. 4733, p. 41-43 doi:10.1126/science.231.4733.41 
Polyak, V.J., McIntosh, W.C., Guven, N., and Provencio, P., 1999, Age and origin of Carlsbad cavern and related caves from 40Ar/39Ar of Alunite: Science, v. 279, i. 5358, p. 19191922, doi: 10.1126/science.279.5358.1919

Polyak, V.J., and Asmerom, Y., 2001, Late Holocene climate and cultural changes in the southwestern United States: Science, v. 294, i. 5540, p. 148-151

doi:10.1126/science.1062771

Ramburg, I. B., Cook, F.A., and Smithson, S.B., 1978, Structure of the Rio Grande Rift in southern New Mexico and west Texas based on gravity interpretation: Geological Society of America Bulletin, v. 89, no. 1, p. 107-123 doi: 10.1130/0016-7606

Reiter, M., and Chamberlin, R.M., 2011, Alternative perspectives of crustal and upper mantle phenomena along the Rio Grande rift, GSA Today, v. 21, no. 2, p. 4-9 doi:10.1130/GSATG79AR

Ritter, D.E., Kochel, R.C., and Miller, J.R., 2011 Process Geomorphology, Waverland Press, INC, Fifth edition, p 85-415

Sabatakakis, N., Koukis, G., Tsiambaos, G., and Papanakli, S., 2008, Index properties and strength variation controlled by microstructure for sedimentary rocks: Engineering Geology, v. 97, i. 1-2 , p. 80-90, doi: 10.1016/j.enggeo.2007.12.004

Schoenmann, S., 2017, Evaluating relationships between rock strength and the geomorphology of longitudinal stream profiles in the southern Guadalupe Mountains, Texas [Masters thesis]: Normal, Illinois State University

Scholle, P.A., Ulmer, D.S., and Melim, L.A., 1992, Late-stage calcites in the Permian Capitan Formation and its equivalents, Delaware Basin Margin, west Texas and New Mexico: evidence for replacement of precursor evaporites: Sedimentology, v. 39, i. 2, p. 207-234 doi: 10.1111/j.1365-3091.1992.tb01035.x

Turko, J.M., and Knuepfer, P.L., 1991, Late Quaternary fault segmentation from analysis of scarp morphology: Journal of Geology, v. 19, i. 7, p. 718-721 doi:10.1130/00917613(1991)019

Wallace, R.E., 1977, Profiles and ages of young fault scarps, north-central Nevada: Geological Society of America Bulletin, v. 88, no. 9, p. 1267-1281

Zreda, M., Noller, J.S., 1998, Ages of prehistoric earthquakes revealed by $\operatorname{cosmogenic}{ }^{36} \mathrm{Cl}$ in a bedrock fault scarp at Hebgen Lake: Science, v. 282, i. 5391, p. 1097-1099 doi:10.1126/science.282.5391.1097 


\section{APPENDIX: COSMOGENIC DATA}

APPENDIX TABLE 1 . SHIELDING FACTOR DATA

Sample ID $\quad$ Azimuth $\left(^{\circ}\right)$

\begin{tabular}{cc}
\hline GMAH-01 & $29.4,45,69.9,117.9,142,142.6,155.9,163.5,173,180.8,185.9,197.3$, \\
& $207.1,213.7,222.5,236.2,243.6,258.7,270.6,282.8,293.8,301,315,328.2$, \\
GMAH-03 & $334.3,356.3$ \\
& $25.5,53.5,61.4,71.0,83.1,107.5,129.3,141.2,145.9,152.5,160.5,171.5$, \\
& $183.1,193.8,205.7,212.5,229,235.5,236.5,238.9,248.2,258.7,275,289.9$, \\
GMAH-04 & $303.5,315.8,335.1,359$ \\
& $5,25.7,41.2,61.6,69.3,78.8,86.5,99.1,106.2,116.4,124.4,127.5,132.6$, \\
& $152.3,159.9,163.4,178.5,188.6,197.8,206,214,223.8,232.2,237.9,238.5$, \\
GMAH-06 & $244.9,259.6,290.7,301.9,333.3$ \\
& $4.24 .4,52.6,60.2,71.5,96,107.1,123.7,148.2,145.1,152.2,159.2,169.6$, \\
GMAH-07 & $181.2,199.7,210.5,215.5,223.2,231,242,245.8,254.4,266,275.3,284.8$, \\
& $297.7,313.3,323.3,341.5$ \\
GMAH-08 & $2.6,26.2,31,41.5,58.4,72.2,89.9,100.4,116.5,124.8,129.6,137.6,148.4$, \\
& $155.5,164.2,169.6,178,188.1,199.5,210.2,218.4,222.3,228.2,237.2$, \\
& $237.8,251.8,259.1,271.8,280.9,293,305.1,335.1,329.2,322.3,347.2$ \\
GMAH-09 & $6.7,22.6,37.6,57.5,77.6,93.6,115,130.3,145.1,165.6,182.3,193.2,208.7$, \\
& $230.7,244.6,252.2,253.3,263.7,270.6,281.3,289.5,301.6,313.8,333.7$, \\
& $3.36 .8,356.4$ \\
WC-01 & $7,21.8,40.1,65,78,90,102.6,118.8,126.5,143.7,162.6,177.3,185.4$, \\
& $198.3,205.8,214.8,229.4,249.3,258.5,259.3,260,267.1,275.9,283.1$, \\
& $293.5,307.8,312.2,323.8,339.2,354.8$
\end{tabular}

(Table Continues) 


\begin{tabular}{|c|c|c|c|}
\hline Inclination $\left({ }^{\circ}\right)$ & Strike & Dip & $\begin{array}{l}\text { Shielding } \\
\text { Factor }\end{array}$ \\
\hline $\begin{array}{l}10.4,21.2,62.6,57.8,40.6,24.7,16.1,13.5,5.9,6.1,3.9 \\
\quad 3.2,3.7,3.5,2.4,1.1,0.8,0.1,0.3,0,0,0,0,0,0,0\end{array}$ & 142 & 41 & 0.8316106 \\
\hline $\begin{array}{c}10.6,19.5,23.1,27,31.4,29.1,23.7,20.6,17.7,15.7,11.7 \\
7.1,5.4,3.9,4.5,4.5,2.8,1.3,1.8,1.6,1.1,1.1,0.2,0.4 \\
0.5,0.0,0.1,3.6\end{array}$ & 120 & 24 & 0.9196984 \\
\hline $\begin{array}{c}60.6,58.4,58.1,51.1,43.9,32.6,25.8,20.1,19.5,15.1 \\
12.2,11,9.7,3,0.2,0.5,0.9,0,0,0,0,0,0.1,0,0,0,0 \\
1.6,53.2\end{array}$ & 34 & 19 & 0.88387156 \\
\hline $\begin{array}{c}30,37.7,38.4,39.1,34.7,25.4,18.4,14.5,2.1,2.4,0,0,- \\
0.3,0.2,0.8,0,0,0,0.3,0,0,0,0,0,0,0,0.6,3.7,14.7\end{array}$ & 143 & 5 & 0.94174154 \\
\hline $\begin{array}{c}12.7,11,10.4,9.2,4.5,6.9,3.6,3.9,2.9,1.8,0.2,0.3,0.3 \\
0.8,0.6,0,0,0,0,0,0,0,0,0.1,0.2,0,0,0,0,0,2.1,9 \\
8.4,6,10\end{array}$ & 230 & 6 & 0.98601909 \\
\hline $\begin{array}{c}24.9,30,33.2,32.6,34.7,28.3,27.3,22.4,18.6,10,3.6 \\
2.4,1.9,1.1,1.1,1.1,1.1,0.9,0.9,0.5,0.4,0.2,0.4,0.2 \\
17.8,15\end{array}$ & 165 & 46 & 0.88235142 \\
\hline $\begin{array}{c}18.1,18.2,38.9,29,24.9,31.3,19.5,16.8,18.4,15.8,9.9 \\
3.5,1.2,1.4,0.7,0.1,0,0,0,0,0,0,0,0,0,0,0,0,4.8 \\
17.5\end{array}$ & 201 & 4 & 0.95155853 \\
\hline $30.5,7.5,7.5,0.6,-1.3,0.7,0,3.5,2.1,10.4$ & 126 & 31 & 0.8572 \\
\hline
\end{tabular}




\begin{tabular}{|c|c|}
\hline $\begin{array}{l}\text { Sample } \\
\text { Name }\end{array}$ & $\begin{array}{l}\text { Scaling } \\
\text { Scheme }\end{array}$ \\
\hline
\end{tabular}

\begin{tabular}{cccccc}
\hline GMAH-01 & De & 31.98783 & -104.8653 & 2154 & 788.9055712 \\
GMAH-03 & De & 31.98988 & -104.8282 & 2120.4 & 792.0570441 \\
GMAH-04 & De & 31.88222 & -104.8814 & 1627.2 & 839.8282618 \\
GMAH-06 & De & 31.88194 & -104.8831 & 1546 & 847.9053798 \\
GMAH-07 & De & 31.33287 & -104.9725 & 1868.7 & 816.350561 \\
GMAH-08 & De & 32.08492 & -104.8148 & 1807.5 & 822.0462343 \\
GMAH-11 & De & 31.97864 & -104.8809 & 1934.57 & 809.7981702 \\
WC-01 & De & 32.3337 & -104.997 & 1381.7 & 864.3935169 \\
& & & & & (Table Continues)
\end{tabular}




$\begin{array}{cccccc}\begin{array}{c}\text { Atmospheric } \\ \text { Pressure and/or } \\ \text { Elevation }\end{array} & \begin{array}{c}\text { Sample } \\ \text { Thickness } \\ (\mathbf{c m})\end{array} & \begin{array}{c}\text { Bulk } \\ \text { Density } \\ \left(\mathbf{g} / \mathrm{cm}^{\mathbf{3}}\right)\end{array} & \begin{array}{c}\text { Shielding } \\ \text { Factor }\end{array} & \begin{array}{c}\text { Erosion } \\ \text { Rate } \\ (\mathbf{m m} / \mathbf{k y r})\end{array} & \begin{array}{c}\text { Conconcentration } \\ { }^{36} \mathbf{C l}(\text { Atoms/g of }\end{array} \\ \text { sample })\end{array}$

\begin{tabular}{lccccc}
\hline Both & 5 & 2.56 & 0.83161064 & 0 & 2880264.973 \\
Both & 5 & 2.56 & 0.9196984 & 0 & 5087589.18 \\
Both & 5 & 2.56 & 0.88387156 & 0 & 1740307.034 \\
Both & 5 & 2.56 & 0.94174154 & 0 & 1896721.995 \\
Both & 5 & 2.56 & 0.98601909 & 0 & 18040220.94 \\
Both & 5 & 2.56 & 0.88235142 & 0 & 6755412.919 \\
Both & 5 & 2.56 & 0.90172033 & 0 & 9566653.011 \\
Both & 5 & 2.56 & 0.8572 & 0 & 19368347.7 \\
& 5 & & & & \\
& 5 & & & & \\
\end{tabular}




\begin{tabular}{|c|c|c|c|c|c|}
\hline $\begin{array}{c}\text { Attenuation } \\
\text { length } \\
\left(\mathrm{g} / \mathrm{cm}^{2}\right)\end{array}$ & $\begin{array}{l}\text { Depth to top } \\
\text { of sample } \\
\text { (cm) }\end{array}$ & $\begin{array}{c}\text { Year } \\
\text { Collected } \\
\text { (Year A.D.) }\end{array}$ & $\begin{array}{c}\text { Water } \\
\text { content } \\
\text { in pores }\end{array}$ & $\begin{array}{c}\text { Mineral } \\
\text { seperation }\end{array}$ & $\begin{array}{l}\mathrm{SiO}_{2} \text { Bulk Rock } \\
\text { (oxide weight \%) }\end{array}$ \\
\hline 160.55986 & 0 & 2016 & 0 & Yes & 3.693984659 \\
\hline 160.47138 & 0 & 2016 & 0 & Yes & 0.29376013 \\
\hline 159.2132 & 0 & 2016 & 0 & Yes & 6.782713085 \\
\hline 158.99017 & 0 & 2016 & 0 & Yes & 12.19047619 \\
\hline 160.15771 & 0 & 2016 & 0 & Yes & 0.4054328 \\
\hline 159.59544 & 0 & 2016 & 0 & Yes & 0.577858881 \\
\hline 159.99026 & 0 & 2016 & 0 & Yes & 1.10357396 \\
\hline 158.30987 & 0 & 2014 & 0 & Yes & 0.711636765 \\
\hline
\end{tabular}




\begin{tabular}{|c|c|c|c|c|}
\hline $\begin{array}{c}\mathrm{TiO}_{2} \text { Bulk Rock } \\
\text { (Oxide weight } \\
\%)\end{array}$ & $\begin{array}{c}\mathrm{Al}_{2} \mathrm{O}_{3} \text { Bulk } \\
\text { Rock } \\
\text { (oxide weight \%) }\end{array}$ & $\begin{array}{c}\mathrm{Fe}_{2} \mathrm{O}_{3} \text { Bulk } \\
\text { Rock } \\
\text { (oxide weight } \\
\% \text { ) }\end{array}$ & $\begin{array}{c}\text { MnO Bulk } \\
\text { Rock (oxide } \\
\text { weight } \%)\end{array}$ & $\begin{array}{c}\text { MgO Bulk } \\
\text { Rock (oxide } \\
\text { weight } \% \text { ) }\end{array}$ \\
\hline 0.085789261 & 1.312071054 & 0.383528462 & 0.015139281 & 18.82317319 \\
\hline 0.015194489 & 0.222852512 & 0.141815235 & 0.013168558 & 20.75567261 \\
\hline 0.036014406 & 0.660264106 & 0.200080032 & 0.006002401 & 0.960384154 \\
\hline 0.061152882 & 0.932330827 & 0.290726817 & 0.007017544 & 3.989974937 \\
\hline 0.00506791 & 0.12162984 & 0.04054328 & 0.003040746 & 21.79201297 \\
\hline 0.007096513 & 0.162206002 & 0.101378751 & 0.01216545 & 22.16139497 \\
\hline 0.013161891 & 0.445479397 & 0.121494381 & 0.023286423 & 21.57537714 \\
\hline 0.004009221 & 0.050115265 & 0.030069159 & 0.003006916 & 21.88032475 \\
\hline
\end{tabular}




\begin{tabular}{ccccc}
$\begin{array}{c}\text { CaO Bulk } \\
\text { Rock } \\
\text { (oxide weight } \\
\text { \%) }\end{array}$ & $\begin{array}{c}\text { Na2O Bulk } \\
\text { Rock } \\
\text { (oxide weight } \\
\text { \%) }\end{array}$ & $\begin{array}{c}\text { K2O Bulk Rock } \\
\text { (oxide weight } \\
\text { \%) }\end{array}$ & $\begin{array}{c}\text { P2O5 Bulk Rock } \\
\text { (oxide weight }\end{array}$ & $\begin{array}{c}\text { Analytical } \\
\text { Water } \\
\text { (oxide weight } \\
\text { \%) }\end{array}$ \\
\hline 30.8033912 & 0.050464271 & 0.252321356 & 0.030278563 & 44.5498587 \\
32.48581848 & 0.040518639 & 0.040518639 & 0.01012966 & 45.98865478 \\
50.6302521 & 0.050020008 & 0.120048019 & 0.120048019 & 40.43617447 \\
43.45864662 & 0.070175439 & 0.240601504 & 0.130325815 & 38.62656642 \\
32.16095682 & 0.07095074 & 0.03040746 & 0.02027164 & 45.35779445 \\
33.78953771 & 0.030413625 & 0.02027575 & 0.02027575 & 43.10624493 \\
33.2388377 & 0.040498127 & 0.020249063 & 0.030373595 & 43.39374304 \\
33.50706625 & 0.060138318 & 0.010023053 & 0.030069159 & 43.71053423 \\
& & & & \\
\hline
\end{tabular}




$\begin{array}{ccccccc}\text { CO2 Bulk Rock } & \text { Cl Bulk } & \text { B Bulk } & \text { Sm Bulk } & \text { Gd Bulk } & \text { U Bulk } & \text { Th Bulk } \\ (\text { oxide weight \%) } & \text { Rock } & \text { Rock } & \text { Rock } & \text { Rock } & \text { Rock } & \text { Rock } \\ (\text { ppm }) & (\text { ppm) } & (\text { ppm }) & (\text { ppm) } & (\text { ppm) } & \text { (ppm) }\end{array}$

\begin{tabular}{|c|c|c|c|c|c|c|}
\hline 43.8 & 0.03 & 27.3 & 0.8 & 0.6 & 0.6 & 1.1 \\
\hline 46.9 & 0.05 & 9.4 & 0.2 & 0.3 & 0.3 & 0.2 \\
\hline 38 & 0.03 & 13.4 & 0.7 & 0.5 & 2.5 & 0.5 \\
\hline 35.1 & 0.03 & 19.3 & 0.9 & 0.9 & 2.5 & 0.8 \\
\hline 46.8 & 0.04 & 4.6 & 0.1 & 0.1 & 1.4 & 0.1 \\
\hline 46.8 & 0.03 & 1.3 & 0.2 & 0.3 & 0.2 & 0.1 \\
\hline 46.2 & 0.03 & 6.2 & 0.5 & 0.7 & 1.9 & 0.2 \\
\hline 46.2 & 0.03 & 0.5 & 0.1 & 0.2 & 2.9 & 0.1 \\
\hline
\end{tabular}




\begin{tabular}{|c|c|c|c|c|c|c|}
\hline $\begin{array}{c}\text { Cr Bulk } \\
\text { Rock } \\
\text { (ppm) }\end{array}$ & $\begin{array}{c}\text { Li Bulk } \\
\text { Rock } \\
\text { (ppm) }\end{array}$ & $\begin{array}{l}\text { Target } \mathrm{K}_{2} \mathrm{O} \\
(\text { weight } \% \text { ) }\end{array}$ & $\begin{array}{c}\text { Target CaO } \\
\text { (weight \%) }\end{array}$ & $\begin{array}{l}\text { Target } \mathrm{TiO}_{2} \\
\text { (weight } \% \text { ) }\end{array}$ & $\begin{array}{c}\text { Target } \\
\mathrm{Fe}_{2} \mathrm{O}_{3} \\
\text { (weight \%) }\end{array}$ & $\begin{array}{c}\text { Target } \\
\text { Cl } \\
\text { (ppm) }\end{array}$ \\
\hline 20 & 0.01 & 0.25 & 30.52 & 0.085 & 0.38 & 536.7 \\
\hline 20 & 0.01 & 0.04 & 32.07 & 0.015 & 0.14 & 329.8 \\
\hline 20 & 0.01 & 0.12 & 50.61 & 0.036 & 0.2 & 257 \\
\hline 30 & 0.01 & 0.24 & 43.35 & 0.061 & 0.29 & 182.7 \\
\hline 20 & 0.01 & 0.03 & 31.73 & 0.005 & 0.04 & 544 \\
\hline 20 & 0.01 & 0.02 & 33.33 & 0.007 & 0.1 & 360.6 \\
\hline 20 & 0.01 & 0.02 & 32.83 & 0.013 & 0.12 & 308.5 \\
\hline 20 & 0.01 & 0.01 & 33.43 & 0.004 & 0.03 & 601.8 \\
\hline
\end{tabular}




\begin{tabular}{|c|c|c|c|c|c|}
\hline $\begin{array}{c}\text { Latitude } \\
\text { Uncertainty } \\
\text { (dd) }\end{array}$ & $\begin{array}{c}\text { Longitude } \\
\text { Uncertainty } \\
\text { (dd) }\end{array}$ & $\begin{array}{c}\text { Elevation } \\
\text { Uncertainty } \\
\text { (m) }\end{array}$ & $\begin{array}{c}\text { Pressure } \\
\text { Uncertainty } \\
\text { (hPa) }\end{array}$ & $\begin{array}{c}\text { Sample } \\
\text { Thickness } \\
\text { Uncertainty } \\
\text { (cm) }\end{array}$ & $\begin{array}{c}\text { Bulk Density } \\
\text { Uncertainty } \\
\left(\mathrm{g} / \mathrm{cm}^{\mathbf{3}}\right)\end{array}$ \\
\hline 0 & 0 & 0.00256 & 0.01000061 & 0.001 & 0.02 \\
\hline 0 & 0 & 0.00256 & 0.01000258 & 0.001 & 0.02 \\
\hline 0 & 0 & 0.00256 & 0.0100089 & 0.001 & 0.02 \\
\hline 0 & 0 & 0.00256 & 0.01004597 & 0.001 & 0.02 \\
\hline 0 & 0 & 0.00256 & 0.01000233 & 0.001 & 0.02 \\
\hline 0 & 0 & 0.00256 & 0.01000198 & 0.001 & 0.02 \\
\hline 0 & 0 & 0.00256 & 0.01000108 & 0.001 & 0.02 \\
\hline 0 & 0 & 0.00256 & 0.01000171 & 0.001 & 0.02 \\
\hline
\end{tabular}




\begin{tabular}{|c|c|c|c|c|}
\hline $\begin{array}{l}\text { Shielding } \\
\text { Factor } \\
\text { Uncertainty }\end{array}$ & $\begin{array}{c}\text { Erosion Rate } \\
\text { Uncertainty } \\
(\mathbf{m m} / \mathbf{k y r})\end{array}$ & $\begin{array}{c}\text { Concentration }{ }^{36} \mathrm{Cl} \\
\text { Uncertainty } \\
\text { (atoms/g of sample) }\end{array}$ & $\begin{array}{l}\text { Attenuation } \\
\text { Length } \\
\text { Uncertainty } \\
\left(\mathrm{g} / \mathrm{cm}^{2}\right)\end{array}$ & $\begin{array}{c}\text { Depth to } \\
\text { Top of } \\
\text { Sample } \\
\text { Uncertainty } \\
\text { (cm) }\end{array}$ \\
\hline 0.000012 & 0 & 335118.7235 & $6.23 \mathrm{E}-08$ & 0 \\
\hline 0.0000109 & 0 & 267947.0678 & $6.23 \mathrm{E}-08$ & 0 \\
\hline 0.0000113 & 0 & 123511.7046 & $6.28 \mathrm{E}-08$ & 0 \\
\hline 0.0000106 & 0 & 122427.508 & 6.29E-08 & 0 \\
\hline 0.0000101 & 0 & 2069967.366 & $6.24 \mathrm{E}-08$ & 0 \\
\hline 0.0000113 & 0 & 976017.0131 & $6.26 \mathrm{E}-08$ & 0 \\
\hline 0.0000111 & 0 & 897867.8447 & $6.25 \mathrm{E}-08$ & 0 \\
\hline 0.0000117 & 0 & 4038495.567 & $6.31 \mathrm{E}-08$ & 0 \\
\hline
\end{tabular}




\begin{tabular}{|c|c|c|c|c|}
\hline $\begin{array}{c}\text { Year } \\
\text { Collected } \\
\text { Uncertainty } \\
\text { (Year A.D.) }\end{array}$ & $\begin{array}{c}\text { Water Content } \\
\text { in Pores } \\
\text { Uncertainty } \\
\text { (volume \%) }\end{array}$ & $\begin{array}{c}\text { Bulk Rock } \mathrm{SiO}_{2} \\
\text { Uncertainty } \\
\text { (oxide weight \%) }\end{array}$ & $\begin{array}{c}\text { Bulk Rock } \mathrm{TiO}_{2} \\
\text { Uncertainty } \\
\text { (oxide weight } \\
\%)\end{array}$ & $\begin{array}{c}\text { Bulk Rock } \mathrm{Al}_{2} \mathrm{O}_{3} \\
\text { Uncertainty } \\
\text { (oxide weight \%) }\end{array}$ \\
\hline
\end{tabular}

\begin{tabular}{llllc}
\hline 0 & 0 & 0.01 & 0.001 & 0.01 \\
0 & 0 & 0.01 & 0.001 & 0.01 \\
0 & 0 & 0.01 & 0.001 & 0.01 \\
0 & 0 & 0.01 & 0.001 & 0.01 \\
0 & 0 & 0.01 & 0.001 & 0.01 \\
0 & 0 & 0.01 & 0.001 & 0.01 \\
0 & 0 & 0.01 & 0.001 & 0.01
\end{tabular}




\begin{tabular}{|c|c|c|c|c|}
\hline $\begin{array}{c}\text { Bulk Rock } \\
\mathrm{Fe}_{2} \mathrm{O}_{3} \\
\text { Uncertainty } \\
\text { (oxide weight } \\
\% \text { ) }\end{array}$ & $\begin{array}{c}\text { Bulk Rock } \\
\text { MnO } \\
\text { Uncertainty } \\
\text { (oxide weight } \\
\% \text { ) }\end{array}$ & $\begin{array}{c}\text { Bulk Rock MgO } \\
\text { Uncertainty } \\
\text { (oxide weight } \\
\%)\end{array}$ & $\begin{array}{c}\text { Bulk Rock } \\
\text { CaO } \\
\text { Uncertainty } \\
\text { (oxide weight } \\
\% \text { ) }\end{array}$ & $\begin{array}{c}\text { Bulk Rock } \\
\text { Na2O } \\
\text { Uncertainty } \\
\text { (oxide weight } \\
\% \text { ) }\end{array}$ \\
\hline 0.01 & 0.001 & 0.01 & 0.01 & 0.01 \\
\hline 0.01 & 0.001 & 0.01 & 0.01 & 0.01 \\
\hline 0.01 & 0.001 & 0.01 & 0.01 & 0.01 \\
\hline 0.01 & 0.001 & 0.01 & 0.01 & 0.01 \\
\hline 0.01 & 0.001 & 0.01 & 0.01 & 0.01 \\
\hline 0.01 & 0.001 & 0.01 & 0.01 & 0.01 \\
\hline 0.01 & 0.001 & 0.01 & 0.01 & 0.01 \\
\hline 0.01 & 0.001 & 0.01 & 0.01 & 0.01 \\
\hline
\end{tabular}




\begin{tabular}{|c|c|c|c|c|c|}
\hline $\begin{array}{c}\text { Bulk Rock } \\
\mathrm{K}_{2} \mathrm{O} \\
\text { Uncertainty } \\
\text { (oxide weight } \\
\% \text { ) }\end{array}$ & $\begin{array}{c}\text { Bulk Rock } \\
\text { P2O5 }_{2} \\
\text { Uncertainty } \\
\text { (oxide } \\
\text { weight \%) }\end{array}$ & $\begin{array}{c}\text { Analytical } \\
\text { Water } \\
\text { Uncertainty } \\
\text { (weight \%) }\end{array}$ & $\begin{array}{c}\text { Bulk Rock } \\
\text { CO2 } \\
\text { Uncertainty } \\
\text { (oxide } \\
\text { weight \%) }\end{array}$ & $\begin{array}{l}\text { Bulk Rock } \\
\text { Cl } \\
\text { Uncertainty } \\
\text { (ppm) }\end{array}$ & $\begin{array}{c}\text { Bulk Rock B } \\
\text { Uncertainty } \\
\quad(\text { ppm })\end{array}$ \\
\hline 0.01 & 0.01 & 0.1 & 0.1 & 0.01 & 0.5 \\
\hline 0.01 & 0.01 & 0.1 & 0.1 & 0.01 & 0.5 \\
\hline 0.01 & 0.01 & 0.1 & 0.1 & 0.01 & 0.5 \\
\hline 0.01 & 0.01 & 0.1 & 0.1 & 0.01 & 0.5 \\
\hline 0.01 & 0.01 & 0.1 & 0.1 & 0.01 & 0.5 \\
\hline 0.01 & 0.01 & 0.1 & 0.1 & 0.01 & 0.5 \\
\hline 0.01 & 0.01 & 0.1 & 0.1 & 0.01 & 0.5 \\
\hline 0.01 & 0.01 & 0.1 & 0.1 & 0.01 & 0.5 \\
\hline
\end{tabular}




\begin{tabular}{|c|c|c|c|c|c|}
\hline $\begin{array}{l}\text { Bulk Rock } \\
\text { Sm } \\
\text { Uncertainty } \\
\text { (ppm) }\end{array}$ & $\begin{array}{c}\text { Bulk Rock } \\
\text { Gd } \\
\text { Uncertainty } \\
\text { (ppm) }\end{array}$ & $\begin{array}{c}\text { Bulk Rock U } \\
\text { Uncertainty } \\
\quad(\text { ppm })\end{array}$ & $\begin{array}{c}\text { Bulk Rock } \\
\text { Th } \\
\text { Uncertainty } \\
\text { (ppm) }\end{array}$ & $\begin{array}{c}\text { Bulk Rock } \\
\text { Cr } \\
\text { Uncertainty } \\
\text { (ppm) }\end{array}$ & $\begin{array}{c}\text { Bulk Rock } \\
\text { Li } \\
\text { Uncertainty } \\
\text { (ppm) }\end{array}$ \\
\hline 0.1 & 0.1 & 0.1 & 0.1 & 20 & 0.01 \\
\hline 0.1 & 0.1 & 0.1 & 0.1 & 20 & 0.01 \\
\hline 0.1 & 0.1 & 0.1 & 0.1 & 20 & 0.01 \\
\hline 0.1 & 0.1 & 0.1 & 0.1 & 20 & 0.01 \\
\hline 0.1 & 0.1 & 0.1 & 0.1 & 20 & 0.01 \\
\hline 0.1 & 0.1 & 0.1 & 0.1 & 20 & 0.01 \\
\hline 0.1 & 0.1 & 0.1 & 0.1 & 20 & 0.01 \\
\hline 0.1 & 0.1 & 0.1 & 0.1 & 20 & $\begin{array}{l}0.01 \\
\text { able Continues }\end{array}$ \\
\hline
\end{tabular}




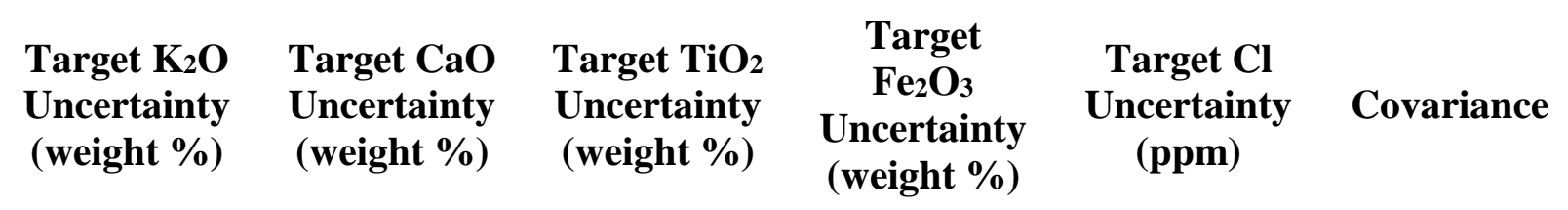

\begin{tabular}{llllcl}
\hline 0.01 & 0.01 & 0.01 & 0.01 & 63.400499 & 0 \\
0.01 & 0.01 & 0.01 & 0.01 & 14.724652 & 0 \\
0.01 & 0.01 & 0.01 & 0.01 & 17.290566 & 0 \\
0.01 & 0.01 & 0.01 & 0.01 & 11.484031 & 0 \\
0.01 & 0.01 & 0.01 & 0.01 & 63.650662 & 0 \\
0.01 & 0.01 & 0.01 & 0.01 & 55.704213 & 0 \\
0.01 & 0.01 & 0.01 & 0.01 & 30.801008 & 0 \\
0.01 & 0.01 & 0.01 & 0.01 & 132.17608 & 0 \\
\hline
\end{tabular}




\begin{tabular}{ccccc}
\hline Sample ID & Latitude (dd) & Longitude (dd) & Elevation (m) & $\begin{array}{c}\text { Elev } \\
\text { Flag }\end{array}$ \\
& & & & \\
GMLH1302 & 32.226767 & -104.878583 & 1835.00 & std \\
GMLH1305 & 32.219517 & & 1607.44 & std \\
GMAH-09 & 32.087897 & -104.883798 & & std \\
\hline
\end{tabular}

$\begin{array}{ccccc}\begin{array}{c}\text { Sample } \\ \text { Thickness } \\ (\mathrm{cm})\end{array} & \begin{array}{c}\text { Sample } \\ \text { Density }\end{array} & \begin{array}{c}\text { Shielding } \\ \text { Factor }\end{array} & \begin{array}{c}\text { Erosion Rate } \\ \left(\mathbf{c m}^{\mathbf{3}}\right)\end{array} & \begin{array}{c}{ }^{10} \text { Be Conconcentration } \\ (\text { atoms } / \mathbf{g})\end{array}\end{array}$

$\begin{array}{lcccc}5.00 & 2.65 & 0.986019088 & 0.00000 & 1345181.01 \\ 5.00 & 2.65 & 0.882351423 & 0.00000 & 467441.49 \\ 5.00 & 2.65 & 0.951558532 & 0.00000 & 436389.43 \\ & & & & \text { (Table Continues) }\end{array}$




\begin{tabular}{ccccc}
\hline $\begin{array}{c}\text { Uncertainty in }{ }^{\mathbf{1 0}} \mathbf{B e} \\
\text { Concentration }\end{array}$ & $\begin{array}{c}\text { Name of Be } \\
\text { Standard }\end{array}$ & $\begin{array}{c}{ }^{\mathbf{2 6}} \mathbf{A l} \\
\text { Conc. }\end{array}$ & $\begin{array}{c}\text { Uncertainty in } \\
{ }^{\mathbf{2 6} A l} \text { Conc. }\end{array}$ & $\begin{array}{c}\text { Name of }{ }^{26} \mathbf{A l} \\
\text { standard }\end{array}$ \\
23551.05 & 07KNSTD & 0 & 0 & KNSTD \\
9663.88 & 07 KNSTD & 0 & 0 & KNSTD \\
7601.83 & 07 KNSTD & 0 & 0 & KNSTD \\
\hline
\end{tabular}

